\title{
Current State of Type 1 Diabetes Immunotherapy: Incremental Advances, Huge Leaps, or More of the Same?
}

\author{
Brett Phillips, ${ }^{1}$ Massimo Trucco, ${ }^{1}$ and Nick Giannoukakis ${ }^{1,2}$ \\ ${ }^{1}$ Division of Immunogenetics, Department of Pediatrics, Children's Hospital of Pittsburgh, University of Pittsburgh School of Medicine, \\ 4401 Penn Avenue, Pittsburgh, PA 15224, USA \\ ${ }^{2}$ Department of Pathology, Children's Hospital of Pittsburgh, University of Pittsburgh School of Medicine, 4401 Penn Avenue, \\ Pittsburgh, PA 15224, USA \\ Correspondence should be addressed to Nick Giannoukakis, ngiann1@pitt.edu
}

Received 17 March 2011; Accepted 28 April 2011

Academic Editor: Aziz Alami Chentoufi

Copyright ( $) 2011$ Brett Phillips et al. This is an open access article distributed under the Creative Commons Attribution License, which permits unrestricted use, distribution, and reproduction in any medium, provided the original work is properly cited.

Thus far, none of the preclinically successful and promising immunomodulatory agents for type 1 diabetes mellitus (T1DM) has conferred stable, long-term insulin independence to diabetic patients. The majority of these immunomodulators are humanised antibodies that target immune cells or cytokines. These as well as fusion proteins and inhibitor proteins all share varying adverse event occurrence and severity. Other approaches have included intact putative autoantigens or autoantigen peptides. Considerable logistical outlays have been deployed to develop and to translate humanised antibodies targeting immune cells, cytokines, and cytokine receptors to the clinic. Very recent phase III trials with the leading agent, a humanised anti-CD3 antibody, call into question whether further development of these biologics represents a step forward or more of the same. Combination therapies of one or more of these humanised antibodies are also being considered, and they face identical, if not more serious, impediments and safety issues. This paper will highlight the preclinical successes and the excitement generated by phase II trials while offering alternative possibilities and new translational avenues that can be explored given the very recent disappointment in leading agents in more advanced clinical trials.

\section{Introduction}

Type 1 diabetes is an autoimmune disease clinically characterized by hyperglycemia underlai by a significant loss of pancreatic insulin-producing beta cell mass. Even though normoglycemia is achieved with pharmacologic insulin replacement, the underlying autoimmune response that impairs and eventually eradicates the beta cells is not treated. Insulin replacement cannot prevent the peripheral complications, a major source of patient morbidity and mortality. Strategies like beta cell replacement with cadaver donor islets still face the impediment of autoimmunity in addition to allogeneic rejection. There is therefore a need to develop methods that directly suppress or eliminate autoimmunity and allow a possible regenerative process.

Activated autoreactive $\mathrm{T}$ cells are the mediator of beta cell destruction and therefore a prime therapeutic target. Other $\mathrm{T}$ cell subpopulations help determine the responsiveness of cytotoxic T-cells. T helper (Th) cells are one of these populations and are divided into 3 groups based on their cytokine production profiles: proinflammatory Th1 and Th17 and anti-inflammatory Th2. The balance of Th cell populations is an important regulator of the immune system and is often examined after immunotherapy treatments, along with anti-inflammatory T-regulatory (Treg) cells. In addition to these cell types, antigen-presenting cells (APCs) such as dendritic cells (DCs) and B cells are responsible for the direct activation of $\mathrm{T}$ cells in response to specific antigens. Various techniques of immunomodulation have been employed in animal models to directly or indirectly regulate cytotoxic T-cell activation utilizing these different target cell populations. Here we will discuss their progress through clinical trials and offer some commentary on whether they represent incremental advances, huge leaps in terms of curative outcome and/or improvement of insulin requirements, or more of the same. 


\section{To Prevent or to Reverse?}

The identification of multiple genetic susceptibility loci over the past decade, when coupled with the presence in high titers of the traditional autoantibody markers in first-degree relatives of T1DM patients, offers a preventive interventional opportunity. By initiating immunomodulation in such preclinically diabetic individuals, it is theoretically possible to mitigate clinical onset of the disease. Statistically, a variety of modeling outcomes suggest that such an approach could be beneficial, although much of the optimism rests on biological data from mouse studies which may not be mirrored in humans. Furthermore, even though genetic and humoral risk may be considerable, they do not always result in clinical disease [75]. The therapist thus faces two dilemmas: (i) are the benefits of prevention worth the risks of the adverse events of current immunomodulation approaches? and (ii) are the benefits of prevention worth the considerable logistical outlays required to screen and treat all those who meet "high-risk" status? The first is the most germane, especially since the long-term effects on the immune system of newer immunomodulation agents are unknown. Furthermore, there are the real risks that latent infections due to dormant viruses could become productive and life threatening as well as the possibility that modulation of immune cells could provoke latent or low-grade autoimmunity other than T1DM. These valid arguments form the cornerstone against which any preventive immunomodulation approach will have to push to successfully enter clinical trials other than phase I safety studies.

On the other hand, attempting immunomodulation in individuals who exhibit clinical disease is better justifiable as the autoimmunity is not speculative (unlike in prevention approaches) but a fact. This then leads to the question of what is considered the point of "too late" at which immunomodulation is ineffective and only adverse events will plague the patient without any possibility of real benefit.

The most straightforward answer is to identify a time window that defines a period between the onset of clinical disease and the last possible point inside which immunomodulation will result in the preservation and/or restoration of a beta cell mass adequate enough to reduce the concentration of, or even obviate, exogenous insulin replacement. Traditionally, this window has been termed the "honeymoon" period; however, a number of studies suggest that it can extend further on, as C-peptide can be detected in adult individuals who have the disease for many years $[76,77]$. The diabetic inflammation of the islets of Langerhans need not be associated with beta cell destruction. It is now well accepted that insulitis impairs beta cell sensing of glucose with/without concomitant impairment in insulin production and secretion in the absence of significant irreversible physical elimination of beta cells [78-80]. Studies also show that beta cells can be differentiated from pancreatic progenitors when inflammation is controlled and suppressed. In fact, under some conditions, suppression of islet inflammation also can be permissive for the replication, even if limited, of existing beta cells [81-84]. The key then is to find a means of first suppressing the islet inflammation to restore the function of residual beta cells and then, once this is secured, to identify a method to ensure that beta-cellreactive $\mathrm{T}$ cells are prevented from reaching the islets and/or that their function is silenced. This second requirement necessitates the establishment of some form of tolerance or regulation of autoreactive immune cells. A product that achieves both concurrently would be best.

\section{Biomarkers of Efficacy}

Although a number of surrogate measurements are accepted in clinical trials, thus far there are no bona fide biomarkers of therapeutic success. The presence of autoantibodies supports the autoimmune nature of T1DM and differentiates it from type 2 diabetes and other forms of metabolic glucohomeostasis impairment, but their disappearance cannot yield information on success of therapies. Cellular proliferation to islet-specific proteins and peptides can differentiate normal from disease-susceptible individuals; however, no causal relationship between disease process and specific cellular response has been established. Frequencies of cell populations in peripheral blood associated with immune regulation (i.e., Foxp3+ Tregs) have been suggested as markers of disease severity and stage and success of immunomodulation, but there is very little functional evidence in support of these propositions. Thus, in the absence of specific and therapyrelated biomarkers, the field has accepted physiologic endpoints as surrogates of therapy efficacy.

In the absence of bona fide biomarkers of immune efficacy, physiologic measurements become of paramount importance. Examples, for T1DM, include maintenance or increase of pretreatment C-peptide levels, improvement of mixed meal-stimulated insulin production and consequent reduction of glucose levels in blood, improvements in glycated $\mathrm{HbAlc}$ and, in certain instances, reduction of exogenously administered insulin or complete cessation thereof for a period of time. As will be discussed later, the values between pretreatment and posttreatment physiological measurements in a number of recent immunomodulation clinical trials, in particular if promoted and implemented close to the clinical onset of the disease, have required stringent statistical analysis to identify differences, and in many respects, the pronouncements of success for some immunomodulation treatments require considerable faith in the outcome of statistical treatments of the data.

The frustration with many immunomodulation trials is the disconnect between preclinical data in mouse and rat models of T1DM and the physiologic outcomes in T1DM patients.

\section{Preclinical Models: Is Efficacy Predictive of Outcome in Humans?}

Currently, there are only two spontaneously occurring, genetically susceptible animal models of T1DM: the heavily popular nonobese diabetic/LtJ strain (NOD) and the diabetes-prone biobreeding rat (BB) [85]. The intensity with which many studies are performed in these two strains 
overlooks some obvious, for the sake of clinical translation, inconvenient facts. First, the two strains are analogous to clones of two individual humans. Second, the differences between man and murine (or rat) immune systems, responses, and immunopathology of T1DM is as different as are the known and perceived similarities [85]. The lymphopenia that characterises the BB rat model is counterintuitive to how autoimmunity develops in this species, even though the target of immune dysfunction and destruction are the islets. Further confounding the issue is the presence of other autoimmunities and inflammatory conditions in the NOD mouse, calling into question just how tissue restricted is its autoimmunity. Another difference lies in the difference in the incidence and prevalence of the disease between female and male NOD mice, a difference that is not observed in humans. The predictable time-at-onset of disease in NOD mice and $\mathrm{BB}$ rats is not as simple to extrapolate to humans. Interindividual heterogeneity in humans lies in the different HLA susceptibility alleles, the non-HLA susceptibility loci, the primary autoantigen(s), and the actual composition of peripheral tolerogenic cell populations that wax and wane during preclinical disease progression. Even at the time of clinical onset, the actual mass of functional and potentially functional residual beta cells is unknown, and this heterogeneity can determine success or failure of a particular immunomodulator.

What is sobering is that, of more than 230 therapeutic strategies employed (to various levels of success) in NOD mice and $\mathrm{BB}$ rats, fewer than ten have proven to be of any clinical utility, and therefore, only a few have progressed to advanced trials $[85,86]$. This should caution the investigator that the outcomes in NOD mice can be instructive for some human patients but not all. The overwhelming number of studies in NOD mice and the few viable therapeutics translated to the clinic offer the following lessons: (i) early prevention is simple in NOD mice (more than 65\% of studies began some form of therapy between 4-6 weeks); (ii) treating new-onset diabetic NOD mice is difficult; (iii) dosage of the agent, especially putative autoantigen peptide formulation may make or break the success; (iv) most studies in NOD mice cease the monitoring at less than 40 weeks of age; (v) nonspecific microbes can influence the outcome in NOD mice. Considerable effort and logistics have been deployed in the past two decades to use insulin administration as a prophylactic intervention [87], and more recently, to employ an anti-CD3 monoclonal antibody in new-onset human disease [88-90]. The optimism and enthusiasm in both these high-profile multicenter trials was supported by data on the resoundingly successful prevention and "reversal of disease" in NOD mice [91-93]. Nevertheless, insulin administration has yet to demonstrate any successful preventive outcome in humans [87, 94-97], and very recent phase III trials of one embodiment of the anti-CD3 antibody failed to reach the primary end-point (http://www.rttnews .com/Content/BreakingNews.aspx? $\mathrm{Id}=1451366 \& \mathrm{~S} \mathrm{M}=1$ \&SimRec=1 and http://www.bizjournals.com/washington/ www.bizjournals.com/washington/quick_news/2010/10/macrogenics-lilly-abandon-diabetes-drug.html). While "more of the same" autoantigen interventions can be justified by the apparent absence of adverse events noted in the insulin trials (and more recent GAD- and HSP-derived peptide studies), the choice of "more of the same" approaches that involve immunodepletion (chemical or biologic agent-mediated), even if supported by data from NOD mice and BB rats, has to be tempered by unsupportive data in advanced trials as well as borderline outcomes in early-phase trials where heavy statistical treatment might be used to demonstrate efficacy, even if minor. Nevertheless, in the absence of any other animal model, the NOD mouse and the $\mathrm{BB}$ rat will continue to be the proving grounds of preclinical efficacy.

\section{Translation of Successful Preclinical Studies into the Clinic: the Outcomes and the Potential in Humans}

The cyclosporin A and the steroid-azathioprine trials proved that established T1DM was reversible [98-100] and, more importantly, that a reserve of beta cell mass was able to restore normoglycemia contingent on suppression of inflammation and autoimmunity [101, 102]. Nevertheless, once cyclosporin A administration was suspended/terminated, the disease reappeared with a vigor no different than that during pretreatment. From a historical perspective, the first successful immunomodulation-based reversal of T1DM was achieved by lymphocyte-specific serum in BB rats [103]. It would be 20 years later that this approach would be attempted in humans [104], although the significant side effects precluded the justification to further explore this approach. Since then, a number of preclinical studies, mainly in NOD mice, have been clinically-translated.

In 1985, Eisenbarth and colleagues reported that steroidsupplemented antithymocyte globulin administration into new-onset T1DM patients reduced insulin requirements. However, this approach was abandoned due to the thrombocytopenia that the procedure was generating [105]. Since then, antithymocyte globulin has been reconsidered and, in new-onset patients, carefully adjusted dosing slowed Cpeptide decline [106]. Antithymocyte globulin binds to the CD3 complex on T cells as one of its many targets and causes significantly greater T-cell depletion. Thus, its justification is hampered by significantly greater adverse events and immunosuppression compared to anti-CD3 antibodies.

The initial excitement generated over insulin administration was tempered by the outcome of a major clinical study which showed few, if any, beneficial outcomes [87]. More recent clinical studies using monoclonal antibodies targeting CD3 and CD20 have also been disappointing despite the convincing and robust successes in preclinical studies $[65,89]$ (http://www.rttnews.com/Content/BreakingNews .aspx? Id=1451366\&SM=1\&SimRec $=1$ and http://www.bizjournals.com/washington/quick_news/2010/10/macrogenicslilly-abandon-diabetes-drug.html).

Long before confirmation in genetic models, insulin and proinsulin were strong contenders as the T1DM-initiating autoantigens [107-114]. As autoantigens, many proposed that the exposure of the T1DM immune system to exogenous insulin in a manner that could modulate immunity towards 
insulin-specific tolerance could prevent disease in prediabetic states and perhaps delay the progression to overt clinical hyperglycemia in more advanced, but subclinical, states [115-118]. Persistent oral insulin treatment of NOD mice delayed T1DM onset and reduced disease incidence in NOD mice [119]. The addition of adjuvants provided a practical benefit in reducing the amount of exogenous insulin required to achieve the beneficial effects [120]. Largely based on the data supporting the view that mucosal delivery of soluble peptides promotes tolerance to them, a number of efforts targeted, in addition to oral, intranasal insulin or insulinderived peptide, aerosolisation into prediabetic NOD mice. In these studies, diabetes was significantly delayed [71, 117, $121,122]$. These very promising studies with what essentially was a simple intervention led to the DPT- 1 multicenter trial which determined the efficacy of oral insulin in first- and second-degree relatives of T1DM patients deemed to fall into high-risk status based on metabolic, immune, and genetic evidence $[73,123]$. Other than a possible benefit in individuals with the highest autoantibody titers, the DPT-1 study failed to delay or prevent T1DM. A similarly disappointing outcome resulted in another prevention trial where insulin was administered intranasally Näntö-Salonen et al, [124]. However, a very small subgroup of autoantibody-positive patients was identified in which some effect was shown. The general view of nonpharmacologic insulin therapy is that, if beneficial, it probably will be restricted to very well-defined and characterised subpopulations of patients. It is unclear what can distinguish these patients from a general at-risk population.

A number of other trials were initiated since then without any significant benefits. The IMDIAB trial showed that oral insulin provided no benefit over placebo after a one-year followup in terms of mean C-peptide secretion and insulin requirements. The ORALE trial, comparing low- with highdose oral insulin $(2.5 \mathrm{mg} /$ day versus $7.5 \mathrm{mg} /$ day $)$, after one year could not discern any benefit in decelerating the loss of physiologic beta cell function [125]. It was recently shown that combined intranasal insulin with $\mathrm{CD} 3$ antibody was able to reverse new-onset T1DM in NOD mice, although the effect was quite likely due to the $\mathrm{CD} 3$ antibody and the characteristics of the NOD mouse cohorts and not due to the insulin [126].

The most recent attempts at using insulin to improve functional beta cell mass involve intramuscular injection of human insulin B chain in incomplete Freund's adjuvant as well as subcutaneous injection of a DNA plasmid vector encoding proinsulin see [127] and http://www.bayhill.bayhilltherapeutics.com/. The outcomes of these proposals rest on the publication of phase II studies which are currently at various stages of implementation.

As strong an argument for GAD can be made in the etiopathogenesis of T1DM as for insulin. The $65 \mathrm{KDa}$ isoform of GAD has been demonstrated to be a target of earlyinsulitic T cells in vitro and in vivo [128, 129]. Administration of GAD into very young NOD mice suppresses anti-GAD T-cell reactivity as well as disease onset $[129,130]$. GAD is equally effective when administered into older NOD mice [130]. The relevance of GAD to human T1DM relies on the presence of GAD autoantibodies in prediabetic humans and is one of three reliable markers of susceptibility [131].

Two clinical trials have used human GAD65 with alum as adjuvant to determine improvement of physiologic beta cell function. One was conducted in LADA patients [132] and determined that this formulation increased fasting and stimulated C-peptide at 24 weeks compared to baseline, a benefit that was associated with an increase of CD4+ CD25+ Tregs. The other study considered the effects of GAD65 in alum in recent-onset T1DM individuals (10-18 years of age) on the rate of decline of stimulated C-peptide [133]. The study revealed a slower rate of decline of stimulated C-peptide in GAD-treated diabetics compared to the placebo group.

Early studies showed that intrathymic administration of Hsp60-derived peptides was prophylactic in NOD mice even though Hsp60 was not considered a bona fide autoantigen involved in T1DM initiation [134]. More experiments in NOD mice revealed that the $\mathrm{p} 277$ peptide of $\mathrm{Hsp} 60$ was quite effective in suppressing disease progression [135]. These data compelled the development of a human equivalent of p277 (DiaPep277; a 24 amino acid synthetic peptide derived from the $\mathrm{C}$ terminus of human hsp60).

DiaPep277 has been evaluated in phase II studies [136], and data demonstrate some degree of preservation of stimulated C-peptide secretion.

Since then, three other studies have been conducted in new-onset T1DM patients [137-139]. In two of these studies, adult patients were the study population, and these recipients exhibited better, yet limited, C-peptide production than placebo-treated individuals. In contrast, DiaPep277 did not offer any objective benefits in young new-onset patients [137].

T-cell depletion targeting the CD3 complex with the OKT3 monoclonal antibody was successfully employed about two decades ago [91]. Administration of the antibody into diabetic NOD mice resulted in complete remission of disease $[91,92]$. One caveat of this particular antibody was that, under some situations, it could activate $\mathrm{T}$ cells and therefore it was not considered suitable for human use. Soon thereafter, FcR nonbinding embodiments were manufactured which exhibited either IgG1 Fc chain or which eliminated glycosylation sites of the original OKT3 clone. These variants were found to be less activating than OKT3 $[140,141]$. Herold and colleagues initially demonstrated that a short-term administration of the nonglycosylated variant into new-onset T1DM patients suppressed the loss of beta cell function as measured indirectly by surrogate physiologic markers [90, 142]. Some patients maintained improved physiologic markers of beta cell function for as much as two years following the treatment in the absence of systemic immunosuppression. A second round of anti-CD3 antibody injections was postulated as necessary to maintain the beneficial outcome. However, additional injections of the antibody were shown to confer more serious, previously undocumented clinical complications.

T1DM is unquestionably a T-cell-mediated disease; however, other cell populations have been implicated in the onset, 
and early progression, of the disease, including B-lymphocytes. Accumulated findings in NOD mice demonstrated that B-cell depletion could be beneficial [143-145], even some studies suggested the contrary [146] where adoptive transfer of T1DM into NOD-SCID mice was possible in the absence of $\mathrm{B}$ cells and antibodies. B cells can also participate in disease exacerbation by promoting epitope spreading as shown by Tian and colleagues [147]. Indeed, capture of autoantigens such as GAD65 by B-cell surface immunoglobulin (Ig) is followed by processing and presentation of T-cell determinants by $B$ cells, a step that is crucial for activation of autoreactive $\mathrm{T}$ cells and induction of diabetes [148-150]. B-cell-mediated processing of self-Ags may contribute to the generation of an inflammatory microenvironment in the pancreas, which is critical for overcoming the regulatory barrier(s) to initiation of diabetes in NOD mice [151]. Antigen-specific B cells and their antibodies are essential in catalyzing determinantspreading reaction via (a) generation of novel previously cryptic epitopes through altered antigen processing or (b) facilitation of T-cell activation through generation of ligands with higher affinity for TCR and delivery of costimulatory signals. Ag processing through surface receptor-mediated internalization, for example, Fc receptors and soluble Ig, is different from that occurring through pinocytosis and phagocytosis [152].

Pescovitz and colleagues demonstrated a small but statistically significant improvement in physiologic markers of beta cell function in new-onset patients [65]. Nevertheless, the improvement was transient as placebo and rituximabtreated patients eventually (by two years) exhibited an identical decline in beta cell function. One possible mechanism could involve the restriction of epitope spreading by B cells after rituximab-mediated deletion, or the repopulation by B-cells that process and present epitopes that compete with diabetes-relevant epitopes.

Autoreactive $\mathrm{T}$ cells have been frequently associated with the production of TH1-type proinflammatory cytokines. It is reasonable, therefore, to use cytokine blockade as a unique or part of a combination therapeutic strategy. IL-1beta, TNFalpha, and type 1 interferons have been historically the first to exhibit direct beta cell cytotoxicity [153-155].

Recently, administration of etanercept, a soluble TNFalpha receptor, in an early-phase efficacy trial resulted in a reduction in the loss of C-peptide in T1DM patients [156]. It is important to note, however, that TNFalpha blockade may have unwanted outcomes; TNFalpha can prevent diabetes in older NOD mice even when splenocytes from diabetic NOD mice are adoptively transferred [157]. Furthermore, TNFalpha blockade may require careful consideration of the age of the individuals being treated since blockade in younger NOD mice prevented disease, while in older NOD mice it accelerated T1DM.

Even though IL-1beta is now known to exert earlyonset impairment in beta cell function and mediates earlyphase recruitment of immune cells into islets [158-161], it is unclear if IL-1beta blockade will have any beneficial outcome in prevention of disease or reversal of new-onset disease. In certain populations characterised by metabolic diabetes (LADA, type 2 diabetes), recent trials with the IL1 receptor antagonist protein (IRAP, Anakinra) improved glucose control [162], and mechanistically it appears that this benefit is achieved by blockade of IL-1beta impairment of immune cell activity (i.e., inflammation) and blockade of IL-1beta effects on beta cell impairment. It is unclear if administration of the IL-1 receptor antagonist protein (Anakinra) will be of any benefit in new-onset cases, especially as the autoimmunity in new-onset disease is largely IL-1beta independent.

\section{Unconventional Therapies That Might Be Clinically Justifiable}

An unexpected recent discovery revolves around the realisation that alpha 1 antitrypsin (A1AT) may possess direct antiinflammatory and perhaps tolerogenic effects, although they are very likely nonantigen specific. A1AT is a serpin whose administration into new onset T1DM NOD mice reversed disease [163]. In addition to its apparent anti-inflammatory effects on insulitis, it promoted regeneration of beta cells and, very likely in an indirect manner, it improved insulin sensitivity. As unclear as the mechanism of action of A1AT may be, equally unclear is the mechanism of another unconventional T1DM treatment using the antileukemia drug, Gleevec [164].

\section{Combination Therapies}

Recent discussions have focused on combining an immunomodulator successful in preventing/reversing T1DM in preclinical studies and human trials with autoantigen(s) and/or biologic agents that on their own improve the function and/or the mass of residual beta cells. These discussions have also proposed combining two or more immunomodulators. Examples include combining the antiCD3 antibody with beta-cell-protective and functionenhancing GLP-1 agonists $[165,166]$, IL-1-neutralising antibodies with the anti-CD3 antibody (http://www.diabetestrialnet.org/studies/index.htm), and anti-CD3 antibodies with traditional pharmacologic immunosuppressives like rapamycin (http://www.diabetestrialnet.org/studies/index.htm).

The problem with these approaches is that the nonanti-CD3 antibody of the combination, on its own had either no effect on prevention or reversal or is not part of any known mechanism that can suppress autoimmunity. Additionally, combining agents where each alone confers obvious side effects could imperil the patient in an additive or multiplicative manner. Last, any benefits a T-cell-depleting antibody may confer on preferential expansion of regulatory $\mathrm{T}$ cells could be negated by the effect of pharmacologic inhibitors on Treg function and differentiation. It is our view that combining biologic agents in the absence of solid preclinical data is premature and potentially harmful. It is also unclear, even in the absence of additive adverse events, what improvement addition of another immunomodulator will have on the benefits of the CD3 antibody. 


\section{Patient-Specific Cell Therapy as a Viable Approach}

In 2007, Voltarelli and colleagues first reported that autologous nonmyeloablative hematopoietic stem cell transplantation preceded by cyclophosphamide, granulocyte-colony stimulating factor (G-CSF) stem cell mobilization, and antithymocyte globulin rendered 14/15 new-onset T1DM patients insulin nonrequiring for an average of 16 months $[167,168]$. It is unclear if such an approach will be approved elsewhere, indeed in children, and the significant toxicity in all patients calls into question whether this approach is justified for an achievement of 16-month insulin-free state. Nevertheless, hematopoietic stem cell transplantation is clinically feasible and offers one means of either repopulating a depleted immune system with a greater contingent of suppressive immune cells compared to pretreatment or establishing tolerance, even transiently. However, existing autoreactive immune cells will still exist and safe approaches to suppress them must still be employed.

Cell therapy, especially with dendritic cells, is a clinical reality that has also recently been accepted by health providers (http://www.provenge.com/). Overwhelming studies indicate that downregulated costimulation capacity in DC can subserve a tolerogenic therapeutic outcome [169-175]. Costimulation-impaired (or downregulated), functionallyimmature DC administration achieves long term and stable allograft survival in a variety of mouse and rat models and prevents a number of autoimmune diseases [176-183]. Mechanistically, functionally immature DCs. act by inducing anergy either via direct cell contact and/or cytokines [172, $184,185]$ or, as described more recently, by upregulating the number and function of immune cell subsets, especially the regulatory populations which include Foxp3+ CD25+ CD4+ $\mathrm{T}$ cells and a class of CD8+ immunosuppressive T cells [186194].

Table 1 lists the models where immature DC administration has proven successful. In addition to anergy, Foxp3+ CD25+ CD4+ T-cell numbers have been observed to be increased by the exogenous supply of tolerogenic DC [195-199]. Immature or semimature DC can induce the differentiation of naturally-occurring (thymic) T regulatory cells (CD4+ CD25+) as well as IL-10-producing CD4+ T cells in vitro and in vivo [195, 198]. Overexpression of the Jagged-1 gene in DC results in the augmentation of antigen-specific TGFbeta-producing CD4+ CD25+ CD4+ Tcells [200]. Functionally immature DCs convert naive T cells into IL-10-secreting cells in vitro, and antigen-pulsed DCs injected subcutaneously into humans augment the number of IL-10-producing CD8+ T cells and trigger a reduction in IFNgamma+ T cells [201, 202]. Despite the abundance of data in support of immature DCs as functional inducers of regulatory immune cells, other investigators have discovered that the state of maturity may not be relevant for the induction of immunosuppressive endogenous T cells. For example, similar to the studies by Morel and colleagues [2], mature DCs were shown to expand CD4+ CD25+ CD4+ Foxp3+ $\mathrm{T}$ cells which were functionally suppressive and capable of preventing diabetes in the NOD mouse [203-205]. Whether this reflects a restimulation of existing CD4+ CD25+ T cells or their expansion is unknown. We have shown that DCs maintained in a functionally immature state following in vitro treatment with NF-kappaB decoys and antisense oligodeoxyribonucleotides (AS-ODNs) to the CD40, CD80, and CD86 costimulatory molecules are diabetes preventive in the NOD mouse $[6,8,206]$ and may involve short-range IL-7 signaling, quite likely inside the pancreatic lymph node of NOD mice, to augment the number of CD4+ CD25+ Treg via suppression of apoptosis of a preexisting pool [206]. Multiple injections of AS-ODN-treated DCs in NOD mice maintained the animals as diabetes free without affecting the overall T-cell activity against alloantigens. Furthermore, repeated administrations of co-stimulation-deficient DC reverses hyperglycemia in new-onset diabetes NOD mice. The promising results from this study, together with the low risk of the procedure, helped in gaining approval by the Food and Drug Administration (FDA) office for a phase I clinical trial which has recently ended with very interesting outcomes, the most important being the complete absence of any adverse events. Adult (18 years or older) volunteers with a documented evidence of insulin-requiring T1D of at least 5 years duration were enrolled. Leukocytes of the patients were obtained by apheresis, and DCs were generated in vitro and engineered in GMP facilities with the addition of AS-ODN. These DCs expressed low levels of CD80, CD86, and CD40 and were then injected into the patient by intradermal/subcutaneous administration at an anatomical site proximal to the pancreas. The choice of this anatomic region for DC delivery was based on the location of the lymphatic conduits (microvessels) that drain the injection site and favor migration to the pancreatic and para-aortic lymph nodes. We conjecture, based on previous rodent studies, that once inside the pancreatic lymph nodes, the injected DCs will acquire molecules that have drained from the pancreas. These molecules can be acquired by passive drainage or can be transferred to the exogenously supplied DC by antigen-presenting cells coming into the pancreatic lymph nodes from apoptotic islets. Therefore, either by direct uptake of "naked" molecules or antigen transfer by migratory antigen-presenting cells, the exogenously administered DC will acquire the antigen specificity. Alternatively, our administered DC could be recruited from the lymph nodes draining the injection site to the apoptotic islets where they could indirectly deliver an anergizing signal to the T cells they encounter. They can also induce regulatory immune cells. The recent concept of contrasuppression, or alternatively, aggregational suppression (network of intercommunicating DC: Treg) could be operative in our system [207-211]. The vicious cycle that promotes the $\mathrm{T}$ cell-mediated anti-betacell-antigen-spreading phenomenon will be interrupted this way, enabling the recovery of the physiologic endocrine function of the gland with time. The abrogation of the autoimmune diabetogenic insult should be sufficient to promote rescue or regeneration of the insulin-producing beta cells in the host endocrine pancreas, even after the onset of the disease. Currently, there are no methods to directly test this mechanism in vivo in humans; however, mouse and nonhuman primate models offer a number of opportunities. 
TABLE 1: Models of immunotherapeutic DC administration to prolong graft survival and to treat autoimmunity.

Autoimmune disease

Type 1 diabetes

(i) Pancreatic lymph node DC (untreated) [1]

(ii) Mature bone-marrow-derived DC (GM-CSF/IL-4 propagated) or transduced with IL-4 vector [2-4], or TGFbeta [5]

(iii) NF-kappaB oligonucleotide decoy propagated or NF-kappaB inhibition [6, 7]

(iv) Antisense oligonucleotide (CD40-, CD80-, CD86-) propagated [8]

(v) Vitamin D receptor ligands $[9,10]$

(vi) Other DC embodiments [11-16]

Thyroiditis

(i) In vitro generation with TNFa and supernatant of a GM-CSF-transduced cell line [17, 18]

(ii) GM-CSF generated followed by in vivo administration of GM-CSF [19]

Experimental encephalomyelitis (Multiple sclerosis model)

(i) In vitro generation with TNFa and supernatant of a GM-CSF-transduced cell line [17, 18]

(ii) VIP and GM-CSF in vitro propagation [20,21]

(iii) TGFbeta and MBP antigen [22]

Myasthenia gravis

(i) RelB knockdown [23]

Arthritis

(i) VIP and GM-CSF in vitro propagation $[20,21]$

(ii) IL-4- or IL-10-expressing bone-marrow-derived DC and derivative exosome preparations [24-26]

(iii) CD95- (Fas ligand-) expressing bone marrow-derived DC [27, 28]

Gastritis

(i) IL-10- expressing DC [29]

Allergy/asthma

(i) IL-10- overexpressing vector [30]

(ii) Allergen overexpression [31]

Allotransplantation/xenotransplantation

Administration of bone-marrow-derived DC from transplant organ donor

(i) DC propagated in low-concentration GM-CSF [32-34]

(ii) DC propagated in GM-CSF, IL-10, TGFb and matured with LPS [35]

(iii) In vitro blockade of NF-kappaB by adding aspirin, vitamin $\mathrm{D}_{3}$ metabolites/analogues, glucosamine, $\mathrm{N}$-acetyl-cysteine, corticosteroids, cyclosporin A, rapamycin, deoxyspergualin, and mycophenolate mofetil [36-51]

(iv) Gene engineering in vitro; DC expressing IL-10, TGFbeta, CTLA-4Ig, indolamine-2,3 dioxygenase, Fas-ligand [52-60]

Administration of transplant-recipient-derived DC prior to transplantation

(i) DC pulsed with class I MHC allopeptide or other alloantigens [61, 62]

(ii) Rapamycin and donor tissue lysate [63]

Table 1 lists the many methods to generate tolerogenic DCs. Some methods converge upon identical cellular and molecular pathways (augmentation of Treg numbers, NFkappaB inhibition, costimulation blockade). Others are not so obvious. A cautionary detail needs insertion herein: it is important to understand that transplantation immunobiology may not be identical to autoimmunity and vice versa. Indeed, there are numerous instances where a therapeutic regimen achieving long-term allograft survival has failed to abrogate autoimmunity [212-219]. Therefore, DCs that are able to suppress donor-specific antigen alloreactivity may not evoke the appropriate regulatory mechanisms capable of controlling and reversing autoimmunity. Also, although different DC products may exhibit similar cell surface phenotypes and nuclear proteome signatures, by no means can this be a predictor of mechanism of action. Cell viability has rarely been examined in these DC products, and not all potential mechanisms of action were considered. It is possible that all listed DC embodiments may intersect at immune regulatory cell levels, but this remains to be determined. The site of action of many DC products, exogenously administered, is currently unknown. While it is generally believed that the DC activity will occur inside the pancreatic lymph nodes, there are equally likely possibilities that the activity of immune tolerance may in fact occur extralymphatically and around the islets, or inside many lymph nodes, anatomically distant from the pancreas. The study by Ludewig and colleagues demonstrating a nascent 
peri-islet lymphoid ultrastructure during diabetes onset is very interesting and instructive and awaits the discovery of a mechanism [220].

Table 1 highlights the studies where animals were treated with tolerogenic DCs pulsed with putative autoantigens. Although the ongoing insulitis drives migration of exogenously administered DCs into the islets, where they acquire the antigen specificity to provide beta cell antigens (from apoptotic/necrotic beta cells) to pancreatic lymph-noderesident regulatory immune cells like Foxp3+ CD25+ CD4+ $\mathrm{T}$ cells, it is currently unknown if ex vivo pulsing with putative autoantigen(s) could stabilize class I MHC to yield more specific Treg in vivo. Our data, however, indicate that the supply of putative autoantigens may not be necessary given the endogenous supply acquired by migratory exogenous DC inside the insulitic lesion. Fathman and colleagues have shown that exogenous DC administration results in preferential accumulation of the DC inside the pancreatic lymph nodes and the omentum [3, 221, 222]. The critical factor in any tissue-targeted approach will be to maintain the DCs in a functionally immature state during and after their accumulation inside that tissue $[6,8,178,180,206]$.

That our CD40-, CD80-, and CD86-impaired DCs exhibited exemplary safety motivates us to proceed with phase II efficacy trials in new-onset T1DM patients with the objective of decelerating the rate of decline of residual beta cell mass, improving glucose profiles, and perhaps reducting insulin requirements. We anticipate beginning such a trial in the next $12-18$ months.

$\mathrm{T}$ regulatory cells (Tregs) are another potential cell population that can be used for suppressing the autoimmunity of T1DM. A variety of methods have been employed to expand natural Tregs and to differentiate induced Tregs from peripheral blood progenitors. These cells have been shown to control ongoing autoimmunity and promote diabetes reversal in NOD mice $[5,223-225]$. It is unclear whether antigen specificity is relevant in this approach because both antigen-specific and nonspecific expanded Tregs are equally efficacious in suppressing T1DM. Furthermore, Tregs recognising one antigen can have a broad effect on suppression effectors reactive to other antigens $[5,205]$. Clinical protocols for T-cell administration into humans exist and patientspecific polyclonal Tregs can, under current conditions, be employed in at least phase I studies.

A particularly interesting discovery very recently indicating that aryl-hydrocarbon receptor-activated CD4+ T cells preferentially differentiate into stably suppressive Foxp3 Tregs, offers therapeutic opportunities that can be exploited by oral route of drug administration [226, 227]. If safe, orally stable aryl hydrocarbon receptor agonists are developed, one could envisage a situation where mucosal CD4+ T-cells could be induced to differentiate into stably suppressive Foxp3+ Tregs. This could be achieved with chemicals or small molecules alone or formulated into nanodelivery particles.

Biopolymers offer a unique platform that can carry antibodies, small molecules, chemical drugs, short sequences of DNA/RNA, and even plasmid vectors [228-231]. Nanoparticles and microspheres in particular can be exploited to deliver immunomodulators on their surface, or inside the polymer matrix. Two recent approaches demonstrate that T1DM can be reversed by administration of microparticles carrying immunomodulatory molecules. We have shown that a microsphere formulation comprised of PEG, polyvinyl pyrrolidone (PVP), and poly-L-lysine-hydrobromide and short antisense oligonucleotides (AS-ODNs) targeting the primary transcripts of the CD40, CD80, and CD86 costimulatory genes effectively prevents and reverses type 1 diabetes in the NOD mouse model [232]. Although the mechanism is not yet fully clear, we propose that the microspheres are taken up following subcutaneous injection (close to an abdominal anatomic site drained in part by the pancreatic lymph nodes) by migratory dendritic cells which then accumulate inside the pancreatic lymph nodes. These dendritic cells exhibit downregulated CD40, CD86, and CD80 costimulation (as a consequence of the effects of the antisense), effectively being turned into tolerogenic dendritic cells. In the pancreatic lymph nodes, these dendritic cells could promote increased regulatory T-cell prevalence which, in an antigen-specific manner, could suppress the activation and overall function of autoreactive T cells. Santamaria and colleagues prevented and reversed new-onset disease using nanoparticlebound autoantigen-derived peptides complexed to MHC proteins. Mechanistically, these investigators showed that the peptide-MHC conjugate was recognised by low peptide-avid autoreactive $\mathrm{CD} 8+\mathrm{T}$ cells that differentiated into regulatory CD8+ $\mathrm{T}$ cells specific for those autoantigen-derived peptides. Furthermore, the use of nanoparticle-conjugated human-relevant peptide-HLA conjugates achieved identical outcomes in human HLA-transgenic diabetic mice [233]. Microparticles offer a unique delivery platform that ranges from injectable to inhalable to topical.

\section{Conclusion and Perspectives}

Table 2 lists past and current immunomodulatory clinical trials and their status. Most have failed to meet their primary end-point. The reasons suggested for the disappointments using autoantigens or derivative peptides can be summarised as follows: (i) the administration route and dosage were not optimal; (ii) peptides may not behave identically to intact proteins and may not promote tolerogenic antigen presentation; (iii) regulatory immune cell responses to peptides are different from protein-derived peptide antigens; (iv) masking critical epitopes in vivo; (v) timing of administration and the stage of disease when the intact autoantigens or autoantigenderived peptides were administered. It is well accepted that advanced-stage disease including clinically T1DM is associated with epitope spreading, so that even if tolerance was achievable to one autoantigen, a number of others that have since appeared would still aggravate autoimmunity.

Reports from recently completed phase III trials using one embodiment of the humanised CD3 antibody were not encouraging. The underlying reasons for why the primary end-points were not achieved, even previous studies were demonstrated to be successful, yet limited in time, are not at all clear at present but could involve one or more of the following: (i) variation among the T1DM patients in actual residual beta cell mass, in that the outcome 
TABLE 2: Clinical trial history for the immunomodulatory treatment of type I diabetes and current state/outcomes.

\begin{tabular}{|c|c|c|c|}
\hline Treatment & Clinical phase & Last update & Notes \\
\hline Anti-CD3 & $\begin{array}{l}\text { Phase III, } \\
\text { canceled }\end{array}$ & 2010 & $\begin{array}{l}\text { Failed to change patient outcomes, and the } \\
\text { phase III study was canceled early [64] }\end{array}$ \\
\hline Anti-CD20 (rituximab) & $\begin{array}{l}\text { Phase II, } \\
\text { completed }\end{array}$ & 2009 & $\begin{array}{l}\text { Beta cell mass preservation, but no change } \\
\text { in C-peptide levels or insulin independence } \\
{[65]}\end{array}$ \\
\hline AS-ODN dendritic cells & $\begin{array}{l}\text { Phase I, } \\
\text { completed }\end{array}$ & 2011 & Treatment safety demonstrated \\
\hline GAD65 protein (Diamyd) & $\begin{array}{l}\text { Phase III, } \\
\text { Ongoing }\end{array}$ & 2010 & $\begin{array}{l}\text { Phase II displayed elevated } \\
\text { anti-inflammatory cytokines and Treg cells. } \\
\text { Insulin independence was not addressed } \\
{[66,67]}\end{array}$ \\
\hline HSP60 (DiaPep277) & $\begin{array}{l}\text { Phase III, } \\
\text { ongoing }\end{array}$ & 2008 & $\begin{array}{l}\text { Phase II trials display a trend of increased } \\
\text { C-peptide levels, anti-inflammatory } \\
\text { cytokines, and anti-inflammatory T-helper } \\
2 \text { cells [68] }\end{array}$ \\
\hline Insulin APL (NBI-6042) & Phase II, failure & 2009 & Beta cell mass was unaffected $[69,70]$ \\
\hline Insulin (intranasal) & Pilot & 2004 & $\begin{array}{l}\text { Decreased T-cell responsiveness to insulin in } \\
\text { patients expressing two to three } \\
\text { diabetes-related autoantibodies }[71,72] \text {. } \\
\text { Additional clinical trials (phase I-III) are } \\
\text { underway }\end{array}$ \\
\hline Insulin (oral) & Phase I, failure & 2005 & $\begin{array}{l}\text { Initial trials showed no prevention or delay } \\
\text { of type } 1 \text { diabetes, but additional trials are } \\
\text { underway }[73,74]\end{array}$ \\
\hline
\end{tabular}

reflects the enrollment of individuals with a more aggressive autoimmunity and hence poorer residual beta cell mass and (ii) the possibility that the time of administration varied between this phase III and previous trials; it is well known that administration of immunomodulatory agents during different times of the day as well as during different points of biologic cycles can profoundly affect the immune response [234-237].

In addition to the anti-CD3 antibody, there are other monoclonal antibodies targeting cytokines as well as fusion proteins interfering with costimulation and serving the role of cytokine decoys. There again, the question is, do these agents represent a promise of a huge leap, an incremental advance, or more of the same? The question is indeed speculative as trials involving some of these agents are ongoing or have not yet started. However, the antibodybased trials are instructive. First, these biologic agents confer variable adverse events. Despite the arguments that these agents can represent antigen-specific approaches, they do not. At best, they promote the homeostatic expansion of new immune cell repertoires that, at various stages of autoimmunity, can act beneficially or can aggravate disease. Recent data indicate that antithymocyte globulin depletion of $\mathrm{T}$ cells promotes the homeostatic expansion of $\mathrm{T}$ cells with a temporally favorable expansion of naturally occurring (thymic) Foxp3+ Tregs [238]. This observation can guide a better approach to promoting homeostatic expansion of Tregs without considerable T-cell depletion and may be instructive for therapies like the anti-CD3 antibody. This phenomenon also appears possible following B-cell depletion with rituximab (i.e., homeostatic expansion of naive B-cells with favorable expansion of B cells with possible regulatory activity [239]). Thus, if consideration is given to understand the timing of repopulation of the periphery with regulatory cells following $\mathrm{T}$-cell or B-cell depletion, more of the same could yield huge leaps in terms of therapeutic success in new onset T1DM.

Another consideration that has been discussed but seldom implemented experimentally is the route of administration of autoantigens and derivative peptides with or without adjuvants or immunomodulators/anti-inflammatory agents. Accumulating evidence suggests that the pancreatic lymph nodes are the major, if not the most important, site of autoimmunity triggering and progression [240-243]. Indeed, regulatory immune cells have been identified to expand and to differentiate from precursors inside draining lymph nodes of tissues that are targets of autoimmunity [207, 244-247]. These observations should be instructive in how to approach ongoing autoimmunity with the aim of inducing antigen-specific suppression. As most, if not all, of pancreatic beta cell antigens are concentrated inside the pancreatic lymph nodes by fluid dynamic flow or are brought inside the pancreatic lymph nodes by antigen-presenting cells, they would drive the acquisition of antigen specificity by immune cells modulated inside the same lymph nodes even by an antigen-nonspecific approach. For example, one could administer costimulation-blocking agents in a manner where they accumulate preferentially inside the pancreatic lymph nodes and allow the bulk flow, or the cross-presentation of beta-cell-derived antigens by antigen-presenting cells that 
have traveled along islet-draining lymphatics, to direct the antigen specificity in conferring antigen-specific immune hyporesponsiveness that is known to occur in response to costimulation blockade.

With the disappointing outcomes of the DPT-1 and related insulin-based trials as well as the failure of industrysponsored phase III trials with one embodiment of the antiCD3 antibody, one could reasonably question the value in pursuing further immunodepletion interventions as well as autoantigen-alone trials. There is merit in the argument that the lack of biomarkers to more precisely measure residual beta cell mass that is functional imperils these studies. There is also merit in the arguments that the time of administration of the agents in the phase of the disease, even in new-onsetcases, is critical and needs a comprehensive evaluation. We argue that more of the same cannot go on without such biomarkers and a better understanding of the balance of immunoregulatory cells between the time of clinical onset and 6-12 months from this time in T1DM patients. The variability in immunoregulatory cell numbers and their function has to be securely identified in large populations. In the meantime, many of the resources of research support have been skewed heavily in these approaches with trepidation of supporting cell therapies that are otherwise safe. We propose that cell therapies be seriously considered for at least phase I studies. Furthermore, a new avenue of studies has emerged which attempts to promote accumulation of immunoregulatory cells inside the pancreatic lymph nodes. A better understanding of the pancreatic lymphatics, we believe, will be important to develop these approaches.

It is now evident that the explosion of obesity in the past ten years confounds the diagnosis of T1DM. Metabolic impairments in glucose homeostasis can mask underlying autoimmunity. Furthermore, obesity-related inflammation in individuals genetically at risk for T1DM could accelerate the onset of autoimmunity. A careful examination of the relationship between obesity-related inflammation and autoimmunity progression, we believe, challenges both the "huge leaps" and the "more of the same" approaches in immunomodulation of T1DM. This is relevant not only for obesity, but for LADA as well. In this regard, it is possible that conditioning the obese patient with anti-inflammatory agents will decelerate and permit the detection of underlying autoimmunity. The suppression of inflammation may be beneficial as a front-line conditioning prior to full immunomodulation.

\section{Conflict of Interests}

Dr. Giannoukakis, Dr. Phillips and Dr. Trucco do not have any conflict of interest related to the agents or the studies referred to in this review.

\section{References}

[1] M. J. Clare-Salzler, J. Brooks, A. Chai, K. Van Herle, and C. Anderson, "Prevention of diabetes in nonobese diabetic mice by dendritic cell transfer," Journal of Clinical Investigation, vol. 90, no. 3, pp. 741-748, 1992.
[2] M. Feili-Hariri, X. Dong, S. M. Alber, S. C. Watkins, R. D. Salter, and P. A. Morel, "Immunotherapy of NOD mice with bone marrow-derived dendritic cells," Diabetes, vol. 48, no. 12, pp. 2300-2308, 1999.

[3] R. J. Creusot, S. S. Yaghoubi, K. Kodama et al., "Tissuetargeted therapy of autoimmune diabetes using dendritic cells transduced to express IL-4 in NOD mice," Clinical Immunology, vol. 127, no. 2, pp. 176-187, 2008.

[4] M. Feili-Hariri, D. H. Falkner, A. Gambotto et al., "Dendritic cells transduced to express interleukin-4 prevent diabetes in nonobese diabetic mice with advanced insulitis," Human Gene Therapy, vol. 14, no. 1, pp. 13-23, 2003.

[5] X. Luo, K. V. Tarbell, H. Yang et al., "Dendritic cells with TGF-betal differentiate naïve $\mathrm{CD} 4^{+} \mathrm{CD} 25^{-} \mathrm{T}$ cells into isletprotective Foxp3+ regulatory $\mathrm{T}$ cells," Proceedings of the National Academy of Sciences of the United States of America, vol. 104, no. 8, pp. 2821-2826, 2007.

[6] L. Ma, S. Qian, X. Liang et al., "Prevention of diabetes in NOD mice by administration of dendritic cells deficient in nuclear transcription factor- $\kappa$ B activity," Diabetes, vol. 52, no. 8, pp. 1976-1985, 2003.

[7] A. Hernandez, M. Burger, B. B. Blomberg et al., "Inhibition of NF- $\kappa \mathrm{B}$ during human dendritic cell differentiation generates anergy and regulatory T-cell activity for one but not two human leukocyte antigen DR mismatches," Human Immunology, vol. 68, no. 9, pp. 715-729, 2007.

[8] J. Machen, J. Harnaha, R. Lakomy, A. Styche, M. Trucco, and N. Giannoukakis, "Antisense oligonucleotides downregulating costimulation confer diabetes-preventive properties to nonobese diabetic mouse dendritic cells," Journal of Immunology, vol. 173, no. 7, pp. 4331-4341, 2004.

[9] L. Adorini and G. Penna, "Induction of tolerogenic dendritic cells by vitamin D receptor agonists," Handbook of Experimental Pharmacology, vol. 188, pp. 251-273, 2009.

[10] L. Adorini, "Tolerogenic dendritic cells induced by vitamin $\mathrm{D}$ receptor ligands enhance regulatory $\mathrm{T}$ cells inhibiting autoimmune diabetes," Annals of the New York Academy of Sciences, vol. 987, pp. 258-261, 2003.

[11] G. Besin, S. Gaudreau, M. Menard, C. Guindi, G. Dupuis, and A. Amrani, "Thymic stromal lymphopoietin and thymic stromal lymphopoietin-conditioned dendritic cells induce regulatory T-cell differentiation and protection of NOD mice against diabetes," Diabetes, vol. 57, no. 8, pp. 2107-2117, 2008.

[12] M. Buckland and G. Lombardi, "Aspirin and the induction of tolerance by dendritic cells," Handbook of Experimental Pharmacology, vol. 188, pp. 197-213, 2009.

[13] H. Kared, A. Masson, H. Adle-Biassette, J. F. Bach, L. Chatenoud, and F. Zavala, "Treatment with granulocyte colony-stimulating factor prevents diabetes in NOD mice by recruiting plasmacytoid dendritic cells and functional $\mathrm{CD} 4^{+} \mathrm{CD} 25^{+}$regulatory T-cells," Diabetes, vol. 54, no. 1, pp. 78-84, 2005.

[14] J. Morin, B. Faideau, M. C. Gagnerault, F. Lepault, C. Boitard, and S. Boudaly, "Passive transfer of flt-3L-derived dendritic cells delays diabetes development in NOD mice and associates with early production of interleukin (IL)-4 and IL10 in the spleen of recipient mice," Clinical and Experimental Immunology, vol. 134, no. 3, pp. 388-395, 2003.

[15] G. Papaccio, F. Nicoletti, F. A. Pisanti, K. Bendtzen, and M. Galdieri, "Prevention of spontaneous autoimmune diabetes in NOD mice by transferring in vitro antigen-pulsed syngeneic dendritic cells," Endocrinology, vol. 141, no. 4, pp. 1500-1505, 2000. 
[16] R. J. Steptoe, J. M. Ritchie, L. K. Jones, and L. C. Harrison, "Autoimmune diabetes is suppressed by transfer of proinsulin-encoding $\mathrm{Gr}-1^{+}$myeloid progenitor cells that differentiate in vivo into resting dendritic cells," Diabetes, vol. 54, no. 2, pp. 434-442, 2005.

[17] M. Menges, S. Rossner, C. Voigtlander et al., "Repetitive injections of dendritic cells matured with tumor necrosis factor alpha induce antigen-specific protection of mice from autoimmunity," The Journal of Experimental Medicine, vol. 195, no. 1, pp. 15-22, 2002.

[18] P. Verginis, H. S. Li, and G. Carayanniotis, "Tolerogenic semimature dendritic cells suppress experimental autoimmune thyroiditis by activation of thyroglobulin-specific CD $4{ }^{+} \mathrm{CD} 25^{+} \mathrm{T}$ cells," Journal of Immunology, vol. 174, no. 11, pp. 7433-7439, 2005.

[19] E. Gangi, C. Vasu, D. Cheatem, and B. S. Prabhakar, "IL10-producing $\mathrm{CD} 4{ }^{+} \mathrm{CD} 25^{+}$regulatory $\mathrm{T}$ cells play a critical role in granulocyte-macrophage colony-stimulating factorinduced suppression of experimental autoimmune thyroiditis," Journal of Immunology, vol. 174, no. 11, pp. 7006-7013, 2005.

[20] A. Chorny, E. Gonzalez-Rey, A. Fernandez-Martin, D. Ganea, and M. Delgado, "Vasoactive intestinal peptide induces regulatory dendritic cells that prevent acute graft-versus-host disease while maintaining the graft-versus-tumor response," Blood, vol. 107, no. 9, pp. 3787-3794, 2006.

[21] A. Chorny, E. Gonzalez-Rey, A. Fernandez-Martin, D. Pozo, D. Ganea, and M. Delgado, "Vasoactive intestinal peptide induces regulatory dendritic cells with therapeutic effects on autoimmune disorders," Proceedings of the National Academy of Sciences of the United States of America, vol. 102, no. 38, pp. 13562-13567, 2005.

[22] D. E. Faunce, A. Terajewicz, and J. Stein-Streilein, "Cutting edge: in vitro-generated tolerogenic APC induce $\mathrm{CD}^{+} \mathrm{T}$ regulatory cells that can suppress ongoing experimental autoimmune encephalomyelitis," Journal of Immunology, vol. 172, no. 4, pp. 1991-1995, 2004.

[23] Y. Zhang, H. Yang, B. Xiao et al., "Dendritic cells transduced with lentiviral-mediated RelB-specific ShRNAs inhibit the development of experimental autoimmune myasthenia gravis," Molecular Immunology, vol. 46, no. 4, pp. 657-667, 2009.

[24] S. H. Kim, S. Kim, C. H. Evans, S. C. Ghivizzani, T. Oligino, and P. D. Robbins, "Effective treatment of established murine collagen-induced arthritis by systemic administration of dendritic cells genetically modified to express IL4," Journal of Immunology, vol. 166, no. 5, pp. 3499-3505, 2001.

[25] S. H. Kim, E. R. Lechman, N. Bianco et al., "Exosomes derived from IL-10-treated dendritic cells can suppress inflammation and collagen-induced arthritis," Journal of Immunology, vol. 174, no. 10, pp. 6440-6448, 2005.

[26] J. D. Whalen, A. W. Thomson, L. Lu, P. D. Robbins, and C. H. Evans, "Viral IL-10 gene transfer inhibits DTH responses to soluble antigens: evidence for involvement of genetically modified dendritic cells and macrophages," Molecular Therapy, vol. 4, no. 6, pp. 543-550, 2001.

[27] S. Hoves, S. W. Krause, D. Halbritter et al., "Mature but not immature Fas Ligand (CD95L)-transduced human monocyte-derived dendritic cells are protected from Fasmediated apoptosis and can be used as killer APC," Journal of Immunology, vol. 170, no. 11, pp. 5406-5413, 2003.
[28] S. Hoves, S. W. Krause, H. Herfarth et al., "Elimination of activated but not resting primary human $\mathrm{CD}^{+}$and $\mathrm{CD}^{+} \mathrm{T}$ cells by Fas ligand (FasL/CD95L)-expressing Killerdendritic cells," Immunobiology, vol. 208, no. 5, pp. 463-475, 2004.

[29] M. Torisu, H. Murakami, F. Akbar et al., "Protective role of interleukin-10-producing regulatory dendritic cells against murine autoimmune gastritis," Journal of Gastroenterology, vol. 43, no. 2, pp. 100-107, 2008.

[30] E. Henry, C. J. Desmet, V. Garzé et al., "Dendritic cells genetically engineered to express IL-10 induce long-lasting antigen-specific tolerance in experimental asthma," Journal of Immunology, vol. 181, no. 10, pp. 7230-7242, 2008.

[31] K. Wu, Y. Bi, K. Sun, J. Xia, Y. Wang, and C. Wang, "Suppression of allergic inflammation by allergen-DNAmodified dendritic cells depends on the induction of Foxp3+ regulatory T cells," Scandinavian Journal of Immunology, vol. 67, no. 2, pp. 140-151, 2008.

[32] F. Fu, Y. Li, S. Qian et al., "Costimulatory molecule-deficient dendritic cell progenitors (MHC class II+, CD80(dim), CD86-) prolong cardiac allograft survival in nonimmunosuppressed recipients," Transplantation, vol. 62, no. 5, pp. 659-665, 1996.

[33] M. B. Lutz, R. M. Suri, M. Niimi et al., "Immature dendritic cells generated with low doses of GM-CSF in the absence of IL-4 are maturation resistant and prolong allograft survival in vivo," European Journal of Immunology, vol. 30, no. 7, pp. 1813-1822, 2000.

[34] C. Rastellini, L. Lu, C. Ricorbi, T. E. Starzl, A. S. Rao, and A. W. Thomson, "Granulocyte/macrophage colony-stimulating factor-stimulated hepatic dendritic cell progenitors prolong pancreatic islet allograft survival," Transplantation, vol. 60, no. 11, pp. 1366-1370, 1995.

[35] K. Sato, N. Yamashita, N. Yamashita, M. Baba, and T. Matsuyama, "Regulatory dendritic cells protect mice from murine acute graft-versus-host disease and leukemia relapse," Immunity, vol. 18, no. 3, pp. 367-379, 2003.

[36] S. Gregori, M. Casorati, S. Amuchastegui, S. Smiroldo, A. M. Davalli, and L. Adorini, "Regulatory T cells induced by 1 alpha,25-dihydroxyvitamin D3 and mycophenolate mofetil treatment mediate transplantation tolerance," The Journal of Immunology, vol. 167, no. 4, pp. 1945-1953, 2001.

[37] M. D. Griffin, W. Lutz, V. A. Phan, L. A. Bachman, D. J. McKean, and R. Kumar, "Dendritic cell modulation by 1alpha,25 dihydroxyvitamin D3 and its analogs: a vitamin $\mathrm{D}$ receptor-dependent pathway that promotes a persistent state of immaturity in vitro and in vivo," Proceedings of the National Academy of Sciences of the United States of America, vol. 98, no. 12, pp. 6800-6805, 2001.

[38] H. Hackstein, A. E. Morelli, A. T. Larregina et al., "Aspirin inhibits in vitro maturation and in vivo immunostimulatory function of murine myeloid dendritic cells," Journal of Immunology, vol. 166, no. 12, pp. 7053-7062, 2001.

[39] H. Hackstein, T. Taner, A. F. Zahorchak et al., "Rapamycin inhibits IL-4-induced dendritic cell maturation in vitro and dendritic cell mobilization and function in vivo," Blood, vol. 101, no. 11, pp. 4457-4463, 2003.

[40] H. Hackstein and A. W. Thomson, "Dendritic cells: emerging pharmacological targets of immunosuppressive drugs," Nature Reviews Immunology, vol. 4, no. 1, pp. 24-34, 2004. 
[41] J. I. Lee, R. W. Ganster, D. A. Geller, G. J. Burckart, A. W. Thomson, and L. Lu, "Cyclosporine A inhibits the expression of costimulatory molecules on in vitro-generated dendritic cells: association with reduced nuclear translocation of nuclear factor kappa B," Transplantation, vol. 68, no. 9, pp. 1255-1263, 1999.

[42] L. Ma, W. A. Rudert, J. Harnaha et al., "Immunosuppressive effects of glucosamine," Journal of Biological Chemistry, vol. 277, no. 42, pp. 39343-39349, 2002.

[43] R. Matasic, A. B. Dietz, and S. Vuk-Pavlovic, "Cyclooxygenase-independent inhibition of dendritic cell maturation by aspirin," Immunology, vol. 101, no. 1, pp. 53-60, 2000.

[44] M. K. Matyszak, S. Citterio, M. Rescigno, and P. RicciardiCastagnoli, "Differential effects of corticosteroids during different stages of dendritic cell maturation," European Journal of Immunology, vol. 30, no. 4, pp. 1233-1242, 2000.

[45] A. Mehling, S. Grabbe, M. Voskort, T. Schwarz, T. A. Luger, and S. Beissert, "Mycophenolate mofetil impairs the maturation and function of murine dendritic cells," Journal of Immunology, vol. 165, no. 5, pp. 2374-2381, 2000.

[46] M. Nouri-Shirazi and E. Guinet, "Direct and indirect crosstolerance of alloreactive $\mathrm{T}$ cells by dendritic cells retained in the immature stage," Transplantation, vol. 74, no. 7, pp. 10351044, 2002.

[47] G. Penna and L. Adorini, "1 Alpha,25-dihydroxyvitamin D3 inhibits differentiation, maturation, activation, and survival of dendritic cells leading to impaired alloreactive $\mathrm{T}$ cell activation," The Journal of Immunology, vol. 164, no. 5, pp. 2405-2411, 2000.

[48] L. Piemonti, P. Monti, P. Allavena et al., "Glucocorticoids affect human dendritic cell differentiation and maturation," Journal of Immunology, vol. 162, no. 11, pp. 6473-6481, 1999.

[49] D. L. Roelen, D. H. Schuurhuis, D. E. M. Van Den Boogaardt et al., "Prolongation of skin graft survival by modulation of the alloimmune response with alternatively activated dendritic cells," Transplantation, vol. 76, no. 11, pp. 1608 1615, 2003.

[50] J. M. Thomas, J. L. Contreras, X. L. Jiang et al., "Peritransplant tolerance induction in macaques: early events reflecting the unique synergy between immunotoxin and deoxyspergualin," Transplantation, vol. 68, no. 11, pp. 16601673, 1999.

[51] O. Vosters, J. Nève, D. De Wit, F. Willems, M. Goldman, and V. Verhasselt, "Dendritic cells exposed to Nacystelyn are refractory to maturation and promote the emergence of alloreactive regulatory T cells," Transplantation, vol. 75, no. 3, pp. 383-389, 2003.

[52] C. A. Bonham, L. Peng, X. Liang et al., "Marked prolongation of cardiac allograft survival by dendritic cells genetically engineered with NF- $\kappa \mathrm{B}$ oligodeoxyribonucleotide decoys and adenoviral vectors encoding CTLA4-Ig," Journal of Immunology, vol. 169, no. 6, pp. 3382-3391, 2002.

[53] P. T. H. Coates, R. Krishnan, S. Kireta, J. Johnston, and G. R. Russ, "Human myeloid dendritic cells transduced with an adenoviral interleukin-10 gene construct inhibit human skin graft rejection in humanized NOD-scid chimeric mice," Gene Therapy, vol. 8, no. 16, pp. 1224-1233, 2001.

[54] R. M. Gorczynski, J. Bransom, M. Cattral et al., "Synergy in induction of increased renal allograft survival after portal vein infusion of dendritic cells transduced to express TGFbeta and IL-10, along with administration of CHO cells expressing the regulatory molecule OX-2," Clinical Immunology, vol. 95, no. 3, pp. 182-189, 2000.
[55] L. Lu, A. Gambotto, W. C. Lee et al., "Adenoviral delivery of CTLA4lg into myeloid dendritic cells promotes their in vitro tolerogenicity and survival in allogeneic recipients," Gene Therapy, vol. 6, no. 4, pp. 554-563, 1999.

[56] W. P. Min, R. Gorczynski, X. Y. Huang et al., "Dendritic cells genetically engineered to express Fas ligand induce donorspecific hyporesponsiveness and prolong allograft survival," Journal of Immunology, vol. 164, no. 1, pp. 161-167, 2000.

[57] R. W. O'Rourke, S. M. Kang, J. A. Lower et al., "A dendritic cell line genetically modified to express CTLA4-Ig as a means to prolong islet allograft survival," Transplantation, vol. 69, no. 7, pp. 1440-1446, 2000.

[58] T. Takayama, A. E. Morelli, P. D. Robbins, H. Tahara, and A. W. Thomson, "Feasibility of CTLA4lg gene delivery and expression in vivo using retrovirally transduced myeloid dendritic cells that induce alloantigen-specific T cell anergy in vitro," Gene Therapy, vol. 7, no. 15, pp. 1265-1273, 2000.

[59] T. Takayama, Y. Nishioka, L. Lu, M. T. Lotze, H. Tahara, and A. W. Thomson, "Retroviral delivery of viral interleukin10 into myeloid dendritic cells markedly inhibits their allostimulatory activity and promotes the induction of Tcell hyporesponsiveness," Transplantation, vol. 66, no. 12, pp. 1567-1574, 1998.

[60] P. Terness, T. M. Bauer, L. Röse et al., "Inhibition of allogeneic $\mathrm{T}$ cell proliferation by indoleamine 2,3-dioxygenaseexpressing dendritic cells: mediation of suppression by tryptophan metabolites," Journal of Experimental Medicine, vol. 196, no. 4, pp. 447-457, 2002.

[61] M. Garrovillo, A. Ali, and S. F. Oluwole, "Indirect allorecognition in acquired thymic tolerance: induction of donorspecific tolerance to rat cardiac allografts by allopeptidepulsed host dendritic cells," Transplantation, vol. 68, no. 12, pp. 1827-1834, 1999.

[62] Y. R. Kuo, C. W. Huang, S. Goto et al., "Alloantigen-pulsed host dendritic cells induce T-cell regulation and prolong allograft survival in a rat model of hindlimb allotransplantation," Journal of Surgical Research, vol. 153, no. 2, pp. 317-325, 2009.

[63] T. Taner, H. Hackstein, Z. Wang, A. E. Morelli, and A. W. Thomson, "Rapamycin-treated, alloantigen-pulsed host dendritic cells induce Ag-specific $\mathrm{T}$ cell regulation and prolong graft survival," American Journal of Transplantation, vol. 5, no. 2, pp. 228-236, 2005.

[64] "Diagnosis and classification of diabetes mellitus," Diabetes Care, vol. 33, supplement 1, pp. S62-S69, 2010.

[65] M. D. Pescovitz, C. J. Greenbaum, H. Krause-Steinrauf et al., "Rituximab, B-lymphocyte depletion, and preservation of beta-cell function," New England Journal of Medicine, vol. 361, no. 22, pp. 2143-2152, 2009.

[66] M. Chéramy, C. Skoglund, I. Johansson, J. Ludvigsson, C. S. Hampe, and R. Casas, "GAD-alum treatment in patients with type 1 diabetes and the subsequent effect on GADA IgG subclass distribution, $\mathrm{GAD}_{65}$ enzyme activity and humoral response," Clinical Immunology, vol. 137, no. 1, pp. 31-40, 2010.

[67] J. Ludvigsson, "Immune intervention in children with type 1 diabetes," Current Diabetes Reports, vol. 10, no. 5, pp. 370$379,2010$.

[68] V. A. L. Huurman, P. E. van der Meide, G. Duinkerken et al., "Immunological efficacy of heat shock protein 60 peptide DiaPep $277^{\mathrm{TM}}$ therapy in clinical type I diabetes," Clinical and Experimental Immunology, vol. 152, no. 3, pp. 488-497, 2008. 
[69] D. G. Alleva, R. A. Maki, A. L. Putnam et al., "Immunomodulation in type 1 diabetes by NBI-6024, an altered peptide ligand of the insulin B epitope," Scandinavian Journal of Immunology, vol. 63, pp. 59-69, 2006.

[70] M. Walter, A. Philotheou, F. Bonnici, A. G. Ziegler, and R. Jimenez, "No effect of the altered peptide ligand NBI-6024 on $\beta$-cell residual function and insulin needs in new-onset type 1 diabetes," Diabetes Care, vol. 32, no. 11, pp. 2036-2040, 2009.

[71] L. C. Harrison, M. Dempsey-Collier, D. R. Kramer, and K. Takahashi, "Aerosol insulin induces regulatory CDS $\gamma \delta$ T cells that prevent murine insulin-dependent diabetes," Journal of Experimental Medicine, vol. 184, no. 6, pp. 2167-2174, 1996.

[72] L. C. Harrison, M. C. Honeyman, C. E. Steele et al., "Pancreatic $\beta$-cell function and immune responses to insulin after administration of intranasal insulin to humans at risk for type 1 diabetes," Diabetes Care, vol. 27, no. 10, pp. 2348 2355, 2004.

[73] J. S. Skyler, J. P. Krischer, J. Wolfsdorf et al., "Effects of oral insulin in relatives of patients with type 1 diabetes: the diabetes prevention trial-type 1," Diabetes Care, vol. 28, no. 5, pp. 1068-1076, 2005.

[74] J. L. Mahon, J. M. Sosenko, L. Rafkin-Mervis et al., "The TrialNet natural history study of the development of type 1 diabetes: objectives, design, and initial results," Pediatric Diabetes, vol. 10, no. 2, pp. 97-104, 2009.

[75] H. T. A. Siljander, S. Simell, A. Hekkala et al., "Predictive characteristics of diabetes-associated autoantibodies among children with HLA-conferred disease susceptibility in the general population," Diabetes, vol. 58, no. 12, pp. 2835-2842, 2009.

[76] M. Abdul-Rasoul, H. Habib, and M. Al-Khouly, "'The honeymoon phase' in children with type 1 diabetes mellitus: frequency, duration, and influential factors," Pediatric Diabetes, vol. 7, no. 2, pp. 101-107, 2006.

[77] F. Lombardo, M. Valenzise, M. Wasniewska et al., "Two-year prospective evaluation of the factors affecting honeymoon frequency and duration in children with insulin dependent diabetes mellitus: the key-role of age at diagnosis," Diabetes, Nutrition and Metabolism, vol. 15, no. 4, pp. 246-251, 2002.

[78] L. Papoz, F. Lenegre, J. Hors et al., "Probability of remission in individual in early adult insulin dependent diabetic patients: results from the cyclosporine diabetes French study group," Diabete et Metabolisme, vol. 16, no. 4, pp. 303-310, 1990.

[79] S. A. Dib and M. B. Gomes, "Etiopathogenesis of type 1 diabetes mellitus: prognostic factors for the evolution of residual beta cell function," Diabetology \& Metabolic Syndrome, vol. 1, article 25, 2009.

[80] H. B. Mortensen, P. Hougaard, P. Swift et al., "New definition for the partial remission period in children and adolescents with type 1 diabetes," Diabetes Care, vol. 32, no. 8, pp. 13841390, 2009.

[81] J. J. Meier, A. Bhushan, A. E. Butler, R. A. Rizza, and P. C. Butler, "Sustained beta cell apoptosis in patients with long-standing type 1 diabetes: indirect evidence for islet regeneration?" Diabetologia, vol. 48, no. 11, pp. 2221-2228, 2005.

[82] N. A. Sherry, J. A. Kushner, M. Glandt, T. Kitamura, A. M. B. Brillantes, and K. C. Herold, "Effects of autoimmunity and immune therapy on $\beta$-cell turnover in type 1 diabetes," Diabetes, vol. 55, no. 12, pp. 3238-3245, 2006.

[83] E. Akirav, J. A. Kushner, and K. C. Herold, " $\beta$-cell mass and type 1 diabetes: going, going, gone?” Diabetes, vol. 57, no. 11, pp. 2883-2888, 2008.
[84] L. Tian, J. Gao, J. Hao et al., "Reversal of new-onset diabetes through modulating inflammation and stimulating betacell replication in nonobese diabetic mice by a dipeptidyl peptidase IV inhibitor," Endocrinology, vol. 151, no. 7, pp. 3049-3060, 2010.

[85] B. O. Roep, M. Atkinson, and M. von Herrath, "Satisfaction (not) guaranteed: re-evaluating the use of animal models of type 1 diabetes," Nature Reviews Immunology, vol. 4, no. 12, pp. 989-997, 2004.

[86] M. A. Atkinson and E. H. Leiter, "The NOD mouse model of type 1 diabetes: as good as it gets?" Nature Medicine, vol. 5, no. 6, pp. 601-604, 1999.

[87] P. Pozzilli, “The DPT-1 trial: a negative result with lessons for future type 1 diabetes prevention," Diabetes/Metabolism Research and Reviews, vol. 18, no. 4, pp. 257-259, 2002.

[88] B. C. Bisikirska and K. C. Herold, "Use of anti-CD3 monoclonal antibody to induce immune regulation in type 1 diabetes," Annals of the New York Academy of Sciences, vol. 1037, pp. 1-9, 2004.

[89] K. C. Herold, S. E. Gitelman, U. Masharani et al., "A single course of anti-CD3 monoclonal antibody hOKT3 $\gamma 1$ (ala-ala) results in improvement in C-peptide responses and clinical parameters for at least 2 years after onset of type 1 diabetes," Diabetes, vol. 54, no. 6, pp. 1763-1769, 2005.

[90] B. Keymeulen, E. Vandemeulebroucke, A. G. Ziegler et al., "Insulin needs after CD3-antibody therapy in new-onset type 1 diabetes," New England Journal of Medicine, vol. 352, no. 25, pp. 2598-2608, 2005.

[91] L. Chatenoud, "Use of CD3 antibodies in transplantation and autoimmune diseases," Transplantation Proceedings, vol. 26, no. 6, pp. 3191-3193, 1994.

[92] L. Chatenoud, J. Primo, and J. F. Bach, "CD3 antibodyinduced dominant self tolerance in overtly diabetic NOD mice," Journal of Immunology, vol. 158, no. 6, pp. 2947-2954, 1997.

[93] L. Chatenoud, "CD3-specific antibody-induced active tolerance: from bench to bedside," Nature Reviews Immunology, vol. 3, no. 2, pp. 123-132, 2003.

[94] J. Ludvigsson, "The role of immunomodulation therapy in autoimmune diabetes," Journal of Diabetes Science and Technology, vol. 3, no. 2, pp. 320-330, 2009.

[95] M. Rewers and P. Gottlieb, "Immunotherapy for the prevention and treatment of type 1 diabetes: human trials and a look into the future," Diabetes Care, vol. 32, no. 10, pp. 1769-1782, 2009.

[96] J. Tian and D. L. Kaufman, "Antigen-based therapy for the treatment of type 1 diabetes," Diabetes, vol. 58, no. 9, pp. 1939-1946, 2009.

[97] D. K. Wherrett and D. Daneman, "Prevention of type 1 diabetes," Endocrinology and Metabolism Clinics of North America, vol. 38, no. 4, pp. 777-790, 2009.

[98] C. R. Stiller, J. Dupre, M. Gent et al., "Effects of cyclosporine immunosuppression in insulin-dependent diabetes mellitus of recent onset," Science, vol. 223, no. 4643, pp. 1362-1367, 1984.

[99] G. Feutren, L. Papoz, R. Assan et al., "Cyclosporin increases the rate and length of remissions in insulin-dependent diabetes of recent onset. Results of a multicentre doubleblind trial," Lancet, vol. 2, no. 8499, pp. 119-124, 1986.

[100] J. Silverstein, N. Maclaren, W. Riley, R. Spillar, D. Radjenovic, and S. Johnson, "Immunosuppression with azathioprine and prednisone in recent-onset insulin-dependent diabetes mellitus," New England Journal of Medicine, vol. 319, no. 10, pp. 599-604, 1988. 
[101] E. Strandell, D. L. Eizirik, and S. Sandler, "Reversal of $\beta$ cell suppression in vitro in pancreatic islets isolated from nonobese diabetic mice during the phase preceding insulindependent diabetes mellitus," Journal of Clinical Investigation, vol. 85, no. 6, pp. 1944-1950, 1990.

[102] S. Sreenan, A. J. Pick, M. Levisetti, A. C. Baldwin, W. Pugh, and K. S. Polonsky, "Increased $\beta$-cell proliferation and reduced mass before diabetes onset in the nonobese diabetic mouse," Diabetes, vol. 48, no. 5, pp. 989-996, 1999.

[103] A. A. Like, A. A. Rossini, D. L. Guberski, M. C. Appel, and R. M. Williams, "Spontaneous diabetes mellitus: reversal and prevention in the $\mathrm{BB} / \mathrm{W}$ rat with antiserum to rat lymphocytes," Science, vol. 206, no. 4425, pp. 1421-1423, 1979.

[104] B. O. Roep, I. Stobbe, G. Duinkerken et al., "Auto- and alloimmune reactivity to human islet allografts transplanted into type 1 diabetic patients," Diabetes, vol. 48, no. 3, pp. 484 490, 1999.

[105] G. S. Eisenbarth, S. Srikanta, R. Jackson et al., "Antithymocyte globulin and prednisone immunotherapy of recent onset type 1 diabetes mellitus," Diabetes Research, vol. 2, no. 6, pp. 271-276, 1985.

[106] F. Saudek, T. Havrdova, P. Boucek, L. Karasova, P. Novota, and J. Skibova, "Polyclonal anti-T-cell therapy for type 1 diabetes mellitus of recent onset," The Review of Diabetic Studies, vol. 1, no. 2, pp. 80-88, 2004.

[107] Y. Fan, W. A. Rudert, M. Grupillo, J. He, G. Sisino, and M. Trucco, "Thymus-specific deletion of insulin induces autoimmune diabetes," EMBO Journal, vol. 28, no. 18, pp. 2812-2824, 2009.

[108] P. Vafiadis, S. T. Bennett, J. A. Todd et al., "Insulin expression in human thymus is modulated by INS VNTR alleles at the IDDM2 locus," Nature Genetics, vol. 15, no. 3, pp. 289-292, 1997.

[109] A. A. Chentoufi and C. Polychronakos, "Insulin expression levels in the thymus modulate insulin-specific autoreactive T-cell tolerance: the mechanism by which the IDDM2 locus may predispose to diabetes," Diabetes, vol. 51, no. 5, pp. 1383-1390, 2002.

[110] A. A. Chentoufi, M. Palumbo, and C. Polychronakos, "Proinsulin expression by Hassall's corpuscles in the mouse thymus," Diabetes, vol. 53, no. 2, pp. 354-359, 2004.

[111] A. Pugliese, M. Zeller, A. Fernandez Jr. et al., "The insulin gene is transcribed in the human thymus and transcription levels correlate with allelic variation at the INS VNTRIDDM2 susceptibility locus for type 1 diabetes," Nature Genetics, vol. 15, no. 3, pp. 293-297, 1997.

[112] D. R. Wegmann and G. S. Eisenbarth, "It's insulin," Journal of Autoimmunity, vol. 15, no. 3, pp. 286-291, 2000.

[113] W. Chen, I. Bergerot, J. F. Elliott et al., "Evidence that a peptide spanning the B-C junction of proinsulin is an early autoantigen epitope in the pathogenesis of type 1 diabetes," Journal of Immunology, vol. 167, no. 9, pp. 4926-4935, 2001.

[114] G. S. Eisenbarth, "Insulin autoimmunity: Iinmunogenetics/immunopathogenesis of type 1A diabetes," Annals of the New York Academy of Sciences, vol. 1005, pp. 109-118, 2003.

[115] P. A. Gottlieb and G. S. Eisenbarth, "Insulin-specific tolerance in diabetes," Clinical Immunology, vol. 102, no. 1, pp. 2-11, 2002.

[116] A. Muir, A. Peck, M. Clare-Salzler et al., "Insulin immunization of nonobese diabetic mice induces a protective insulitis characterized by diminished intraislet interferon- $\gamma$ transcription," Journal of Clinical Investigation, vol. 95, no. 2, pp. 628-634, 1995.
[117] D. Daniel and D. R. Wegmann, "Protection of nonobese diabetic mice from diabetes by intranasal or subcutaneous administration of insulin peptide B-(9-23)," Proceedings of the National Academy of Sciences of the United States of America, vol. 93, no. 2, pp. 956-960, 1996.

[118] B. Hartmann, K. Bellmann, I. Ghiea, R. Kleemann, and H. Kolb, "Oral insulin for diabetes prevention in NOD mice: potentiation by enhancing Th2 cytokine expression in the gut through bacterial adjuvant," Diabetologia, vol. 40, no. 8, pp. 902-909, 1997.

[119] Z. J. Zhang, L. Davidson, G. Eisenbarth, and H. L. Weiner, "Suppression of diabetes in nonobese diabetic mice by oral administration of porcine insulin," Proceedings of the National Academy of Sciences of the United States of America, vol. 88, no. 22, pp. 10252-10256, 1991.

[120] I. Bergerot, C. Ploix, J. Petersen et al., "A cholera toxoidinsulin conjugate as an oral vaccine against spontaneous autoimmune diabetes," Proceedings of the National Academy of Sciences of the United States of America, vol. 94, no. 9, pp. 4610-4614, 1997.

[121] C. Aspord and C. Thivolet, "Nasal administration of CTBinsulin induces active tolerance against autoimmune diabetes in non-obese diabetic (NOD) mice," Clinical and Experimental Immunology, vol. 130, no. 2, pp. 204-211, 2002.

[122] W. Chen, I. Bergerot, J. F. Elliott et al., "Evidence that a peptide spanning the B-C junction of proinsulin is an early autoantigen epitope in the pathogenesis of type 1 diabetes," Journal of Immunology, vol. 167, no. 9, pp. 4926-4935, 2001.

[123] J. M. Sosenko, J. P. Palmer, C. J. Greenbaum et al., "Patterns of metabolic progression to type 1 diabetes in the diabetes prevention trial-type 1," Diabetes Care, vol. 29, no. 3, pp. 643-649, 2006.

[124] K. Näntö-Salonen, A. Kupila, S. Simell et al. et al., "Nasal insulin to prevent type 1 diabetes in children with HLA genotypes and autoantibodies conferring increased risk of disease: a double-blind, randomised controlled trial," Lancet., vol. 372, no. 9651, pp. 1746-1755, 2008.

[125] L. Chaillous, H. Lefevre, C. Thivolet et al., "Oral insulin administration and residual beta-cell function in recentonset type 1 diabetes: a multicentre randomised controlled trial. Diabete Insuline Orale group," Lancet, vol. 356, no. 9229, pp. 545-549, 2000.

[126] D. Bresson, L. Togher, E. Rodrigo et al., "Anti-CD3 and nasal proinsulin combination therapy enhances remission from recentonset autoimmune diabetes by inducing Tregs," Journal of Clinical Investigation, vol. 116, no. 5, pp. 1371-1381, 2006.

[127] T. Orban, K. Farkas, H. Jalahej et al., "Autoantigen-specific regulatory $\mathrm{T}$ cells induced in patients with type 1 diabetes mellitus by insulin B-chain immunotherapy," Journal of Autoimmunity, vol. 34, no. 4, pp. 408-415, 2010.

[128] D. L. Kaufman, M. Clare-Salzler, J. Tian et al., "Spontaneous loss of T-cell tolerance to glutamic acid decarboxylase in murine insulin-dependent diabetes," Nature, vol. 366, no. 6450, pp. 69-72, 1993.

[129] R. Tisch, X. D. Yang, S. M. Singer, R. S. Liblau, L. Fugger, and H. O. McDevitt, "Immune response to glutamic acid decarboxylase correlates with insulitis in non-obese diabetic mice," Nature, vol. 366, no. 6450, pp. 72-75, 1993.

[130] J. Tian, M. Clare-Salzler, A. Herschenfeld et al., "Modulating autoimmune responses to GAD inhibits disease progression and prolongs islet graft survival in diabetes-prone mice," Nature Medicine, vol. 2, no. 12, pp. 1348-1353, 1996. 
[131] R. D. G. Leslie, M. A. Atkinson, and A. L. Notkins, "Autoantigens IA-2 and GAD in Type I (insulin-dependent) diabetes," Diabetologia, vol. 42, no. 1, pp. 3-14, 1999.

[132] C. D. Agardh, C. M. Cilio, Å. Lethagen et al., "Clinical evidence for the safety of GAD65 immunomodulation in adult-onset autoimmune diabetes," Journal of Diabetes and its Complications, vol. 19, no. 4, pp. 238-246, 2005.

[133] J. Ludvigsson, M. Faresjö, M. Hjorth et al., "GAD treatment and insulin secretion in recent-onset type 1 diabetes," New England Journal of Medicine, vol. 359, no. 18, pp. 1909-1920, 2008.

[134] M. A. Atkinson, L. A. Holmes, D. W. Scharp, P. E. Lacy, and N. K. Maclaren, "No evidence for serological autoimmunity to islet cell heat shock proteins in insulin dependent diabetes," Journal of Clinical Investigation, vol. 87, no. 2, pp. 721-724, 1991.

[135] D. Elias and I. R. Cohen, "Treatment of autoimmune diabetes and insulitis in NOD mice with heat shock protein 60 peptide p277," Diabetes, vol. 44, no. 9, pp. 1132-1138, 1995.

[136] V. A. L. Huurman, K. Decochez, C. Mathieu, I. R. Cohen, and B. O. Roep, "Therapy with the hsp50 peptide DiaPep277 ${ }^{\mathrm{TM}}$ in C-peptide positive type 1 diabetes patients," Diabetes/Metabolism Research and Reviews, vol. 23, no. 4, pp. 269-275, 2007.

[137] N. C. Schloot, G. Meierhoff, C. Lengyel et al., "Effect of heat shock protein peptide DiaPep277 on beta-cell function in paediatric and adult patients with recent-onset diabetes mellitus type 1: two prospective, randomized, double-blind phase II trials," Diabetes/Metabolism Research and Reviews, vol. 23, no. 4, pp. 276-285, 2007.

[138] L. Lazar, R. Ofan, N. Weintrob et al., "Heat-shock protein peptide DiaPep277 treatment in children with newly diagnosed type 1 diabetes: a randomised, double-blind phase II study," Diabetes/Metabolism Research and Reviews, vol. 23, no. 4, pp. 286-291, 2007.

[139] I. Raz, D. Elias, A. Avron, M. Tamir, M. Metzger, and I. R. Cohen, " $\beta$-cell function in new-onset type 1 diabetes and immunomodulation with a heat-shock protein peptide (DiaPep277): a randomised, double-blind, phase II trial," Lancet, vol. 358, no. 9295, pp. 1749-1753, 2001.

[140] B. C. Bisikirska and K. C. Herold, "Regulatory T cells and type 1 diabetes," Current Diabetes Reports, vol. 5, no. 2, pp. 104-109, 2005.

[141] K. C. Herold and L. Taylor, "Treatment of Type 1 diabetes with anti-CD3 monoclonal antibody: induction of immune regulation?" Immunologic Research, vol. 28, no. 2, pp. 141150, 2003.

[142] K. C. Herold, W. Hagopian, J. A. Auger et al., "Anti-CD3 monoclonal antibody in new-onset type 1 diabetes mellitus," New England Journal of Medicine, vol. 346, no. 22, pp. 16921698, 2002.

[143] D. V. Serreze, H. D. Chapman, D. S. Varnum et al., "B lymphocytes are essential for the initiation of T cell-mediated autoimmune diabetes: analysis of a new 'speed congenic' stock of NOD.Ig $\mu$ (null) mice," Journal of Experimental Medicine, vol. 184, no. 5, pp. 2049-2053, 1996.

[144] C. Y. Hu, D. Rodriguez-Pinto, W. Du et al., "Treatment with CD20-specific antibody prevents and reverses autoimmune diabetes in mice," Journal of Clinical Investigation, vol. 117, no. 12, pp. 3857-3867, 2007.

[145] Y. Xiu, C. P. Wong, J. D. Bouaziz et al., "B lymphocyte depletion by CD20 monoclonal antibody prevents diabetes in nonobese diabetic mice despite isotype-specific differences in Fc $\gamma$ R effector functions," Journal of Immunology, vol. 180, no. 5, pp. 2863-2875, 2008.

[146] B. J. Miller, M. C. Appel, J. J. O’Neil, and L. S. Wicker, "Both the Lyt-2+ and L3T4+ T cell subsets are required for the transfer of diabetes in nonobese diabetic mice," Journal of Immunology, vol. 140, no. 1, pp. 52-58, 1988.

[147] J. Tian, D. Zekzer, Y. Lu, H. Dang, and D. L. Kaufman, “B cells are crucial for determinant spreading of $\mathrm{T}$ cell autoimmunity among $\beta$ cell antigens in diabetes-prone nonobese diabetic mice," Journal of Immunology, vol. 176, no. 4, pp. 2654-2661, 2006.

[148] M. Falcone, J. Lee, G. Patstone, B. Yeung, and N. Sarvetnick, "B lymphocytes are crucial antigen-presenting cells in the pathogenic autoimmune response to GAD65 antigen in nonobese diabetic mice," Journal of Immunology, vol. 161, no. 3, pp. 1163-1168, 1998.

[149] D. V. Serreze, S. A. Fleming, H. D. Chapman, S. D. Richard, E. H. Leiter, and R. M. Tisch, "B lymphocytes are critical antigen-presenting cells for the initiation of T cell-mediated autoimmune diabetes in nonobese diabetic mice," Journal of Immunology, vol. 161, no. 8, pp. 3912-3918, 1998.

[150] P. A. Silveira, E. Johnson, H. D. Chapman, T. Bui, R. M. Tisch, and D. V. Serreze, "The preferential ability of B lymphocytes to act as diabetogenic APC in NOD mice depends on expression of self-antigen-specific immunoglobulin receptors," European Journal of Immunology, vol. 32, no. 12, pp. 3657-3666, 2002.

[151] S. A. W. Greeley, D. J. Moore, H. Noorchashm et al., "Impaired activation of islet-reactive CD4 T cells in pancreatic lymph nodes of B cell-deficient nonobese diabetic mice," Journal of Immunology, vol. 167, no. 8, pp. 4351-4357, 2001.

[152] H. Reijonen, T. L. Daniels, A. Lernmark, and G. T. Nepom, "GAD65-specific autoantibodies enhance the presentation of an immunodominant T-cell epitope from GAD65," Diabetes, vol. 49, no. 10, pp. 1621-1626, 2000.

[153] A. Rabinovitch, W. Sumoski, R. V. Rajotte, and G. L. Warnock, "Cytotoxic effects of cytokines on human pancreatic islet cells in monolayer culture," Journal of Clinical Endocrinology and Metabolism, vol. 71, no. 1, pp. 152-156, 1990.

[154] A. Rabinovitch, "An update on cytokines in the pathogenesis of insulin-dependent diabetes mellitus," Diabetes/Metabolism Reviews, vol. 14, no. 2, pp. 129-151, 1998.

[155] A. Rabinovitch, W. L. Suarez-Pinzon, K. Strynadka et al., "Human pancreatic islet beta-cell destruction by cytokines is independent of nitric oxide production," The Journal of Clinical Endocrinology \& Metabolism, vol. 79, no. 4, pp. 10581062, 1994.

[156] L. Mastrandrea, J. Yu, T. Behrens et al., "Etanercept treatment in children with new-onset type 1 diabetes: pilot randomized, placebo-controlled, double-blind study," Diabetes Care, vol. 32, no. 7, pp. 1244-1249, 2009.

[157] C. O. Jacob, S. Aiso, S. A. Michie, H. O. McDevitt, and H. Acha-Orbea, "Prevention of diabetes in nonobese diabetic mice by tumor necrosis factor (TNF): similarities between TNF-alpha and interleukin 1," Proceedings of the National Academy of Sciences of the United States of America, vol. 87, no. 3, pp. 968-972, 1990.

[158] C. A. Dinarello, "Interleukin- $1 \beta$ and the autoinflammatory diseases," New England Journal of Medicine, vol. 360, no. 23, pp. 2467-2470, 2009.

[159] C. A. Dinarello, "Immunological and inflammatory functions of the interleukin-1 family," Annual Review of Immunology, vol. 27, pp. 519-550, 2009. 
[160] C. A. Dinarello, "Interleukin-1 in the pathogenesis and treatment of inflammatory diseases," Blood, vol. 117, no. 14, pp. 3720-3732, 2011.

[161] C. A. Dinarello, "Blocking interleukin-1beta in acute and chronic autoinflammatory diseases," Journal of Internal Medicine, vol. 269, pp. 16-28, 2011.

[162] M. Y. Donath and T. Mandrup-Poulsen, "The use of interleukin-1-receptor antagonists in the treatment of diabetes mellitus," Nature Clinical Practice Endocrinology and Metabolism, vol. 4, no. 5, pp. 240-241, 2008.

[163] M. Koulmanda, M. Bhasin, L. Hoffman et al., "Curative and beta cell regenerative effects of alpha1-antitrypsin treatment in autoimmune diabetic NOD mice," Proceedings of the National Academy of Sciences of the United States of America, vol. 105, no. 42, pp. 16242-16247, 2008.

[164] C. Louvet, G. L. Szot, J. Lang et al., "Tyrosine kinase inhibitors reverse type 1 diabetes in nonobese diabetic mice," Proceedings of the National Academy of Sciences of the United States of America, vol. 105, no. 48, pp. 18895-18900, 2008.

[165] N. Ogawa, J. F. List, J. F. Habener, and T. Maki, "Cure of overt diabetes in NOD mice by transient treatment with antilymphocyte serum and exendin-4," Diabetes, vol. 53, no. 7, pp. 1700-1705, 2004.

[166] N. A. Sherry, W. Chen, J. A. Kushner et al., "Exendin-4 improves reversal of diabetes in NOD mice treated with antiCD3 monoclonal antibody by enhancing recovery of $\beta$-cells," Endocrinology, vol. 148, no. 11, pp. 5136-5144, 2007.

[167] C. E. Couri, M. C. Oliveira, A. B. Stracieri et al., "C-peptide levels and insulin independence following autologous nonmyeloablative hematopoietic stem cell transplantation in newly diagnosed type 1 diabetes mellitus," Journal of the American Medical Association, vol. 301, no. 15, pp. 1573 1579, 2009.

[168] J. C. Voltarelli, C. E. Couri, A. B. Stracieri et al., "Autologous nonmyeloablative hematopoietic stem cell transplantation in newly diagnosed type 1 diabetes mellitus," Journal of the American Medical Association, vol. 297, no. 14, pp. 15681576, 2007.

[169] P. Toby, H. Coates, and A. W. Thomson, "Dendritic cells, tolerance induction and transplant outcome," American Journal of Transplantation, vol. 2, no. 4, pp. 299-307, 2002.

[170] H. Hackstein, A. E. Morelli, and A. W. Thomson, "Designer dendritic cells for tolerance induction: guided not misguided missiles," Trends in Immunology, vol. 22, no. 8, pp. 437-442, 2001.

[171] A. E. Morelli and A. W. Thomson, "Dendritic cells: regulators of alloimmunity and opportunities for tolerance induction," Immunological Reviews, vol. 196, pp. 125-146, 2003.

[172] M. Nouri-Shirazi and A. W. Thomson, "Dendritic cells as promoters of transplant tolerance," Expert Opinion on Biological Therapy, vol. 6, no. 4, pp. 325-339, 2006.

[173] R. M. Steinman, D. Hawiger, and M. C. Nussenzweig, "Tolerogenic dendritic cells," Annual Review of Immunology, vol. 21, pp. 685-711, 2003.

[174] R. M. Steinman, K. Inaba, S. Turley, P. Pierre, and I. Mellman, "Antigen capture, processing, and presentation by dendritic cells: recent cell biological studies," Human Immunology, vol. 60, no. 7, pp. 562-567, 1999.

[175] R. M. Steinman and M. C. Nussenzweig, "Avoiding horror autotoxicus: the importance of dendritic cells in peripheral T cell tolerance," Proceedings of the National Academy of Sciences of the United States of America, vol. 99, no. 1, pp. 351-358, 2002 .
[176] R. Bottino, P. Lemarchand, M. Trucco, and N. Giannoukakis, "Gene- and cell-based therapeutics for type I diabetes mellitus," Gene Therapy, vol. 10, no. 10, pp. 875-889, 2003.

[177] D. Chen, R. Sung, and J. S. Bromberg, "Gene therapy in transplantation," Transplant Immunology, vol. 9, no. 2-4, pp. 301-314, 2002

[178] N. Giannoukakis, W. A. Rudert, P. D. Robbins, and M. Trucco, "Targeting autoimmune diabetes with gene therapy," Diabetes, vol. 48, no. 11, pp. 2107-2121, 1999.

[179] N. Giannoukakis, A. W. Thomson, and P. D. Robbins, "Gene therapy in transplantation," Gene Therapy, vol. 6, no. 9, pp. 1499-1511, 1999.

[180] N. Giannoukakis and M. Trucco, "Gene therapy for type 1 diabetes," American Journal of Therapeutics, vol. 12, pp. 512528, 2005.

[181] I. H. Tarner and C. G. Fathman, "The potential for gene therapy in the treatment of autoimmune disease," Clinical Immunology, vol. 104, no. 3, pp. 204-216, 2002.

[182] I. H. Tarner, A. J. Slavin, J. McBride et al., "Treatment of autoimmune disease by adoptive cellular gene therapy," Annals of the New York Academy of Sciences, vol. 998, pp. 512519, 2003.

[183] M. Trucco, P. D. Robbins, A. W. Thomson, and N. Giannoukakis, "Gene therapy strategies to prevent autoimmune disorders," Current Gene Therapy, vol. 2, no. 3, pp. 341-354, 2002.

[184] W. Chen, "Dendritic cells and $\mathrm{CD}^{+} \mathrm{CD} 25^{+} \mathrm{T}$ regulatory cells: crosstalk between two professionals in immunity versus tolerance," Frontiers in Bioscience, vol. 11, pp. 1360-1370, 2006.

[185] S. Hugues, A. Boissonnas, S. Amigorena, and L. Fetler, "The dynamics of dendritic cell-T cell interactions in priming and tolerance," Current Opinion in Immunology, vol. 18, no. 4, pp. 491-495, 2006.

[186] S. Beissert, A. Schwarz, and T. Schwarz, "Regulatory T cells," Journal of Investigative Dermatology, vol. 126, no. 1, pp. 1524, 2006.

[187] A. H. Enk, "DCs and cytokines cooperate for the induction of tregs," Ernst Schering Research Foundation Workshop, no. 56, pp. 97-106, 2006.

[188] S. Huber and C. Schramm, "TGF-beta and CD $4{ }^{+} \mathrm{CD} 25^{+}$ regulatory T cells," Frontiers in Bioscience, vol. 11, pp. 10141023, 2006.

[189] J. Lohr, B. Knoechel, and A. K. Abbas, "Regulatory T cells in the periphery," Immunological Reviews, vol. 212, pp. 149-162, 2006.

[190] M. G. Roncarolo, S. Gregori, M. Battaglia, R. Bacchetta, K. Fleischhauer, and M. K. Levings, "Interleukin-10-secreting type 1 regulatory T cells in rodents and humans," Immunological Reviews, vol. 212, pp. 28-50, 2006.

[191] E. M. Shevach, R. A. DiPaolo, J. Andersson, D. M. Zhao, G. L. Stephens, and A. M. Thornton, "The lifestyle of naturally occurring CD4CD25 Foxp3 regulatory T cells," Immunological Reviews, vol. 212, pp. 60-73, 2006.

[192] Q. Tang and J. A. Bluestone, "Regulatory T-cell physiology and application to treat autoimmunity," Immunological Reviews, vol. 212, pp. 217-237, 2006.

[193] J. Verhagen, K. Blaser, C. A. Akdis, and M. Akdis, "Mechanisms of allergen-specific immunotherapy: T-regulatory cells and more," Immunology and Allergy Clinics of North America, vol. 26, no. 2, pp. 207-231, 2006. 
[194] L. Zhang, H. Yi, X. P. Xia, and Y. Zhao, "Transforming growth factor-beta: an important role in $\mathrm{CD} 4^{+} \mathrm{CD} 25^{+}$regulatory $\mathrm{T}$ cells and immune tolerance," Autoimmunity, vol. 39, no. 4, pp. 269-276, 2006.

[195] M. Battaglia, S. Gregori, R. Bacchetta, and M.-G. Roncarolo, "Tr1 cells: from discovery to their clinical application," Seminars in Immunology, vol. 18, no. 2, pp. 120-127, 2006.

[196] F. J. D. Mennechet and G. Uzé, "Interferon- $\lambda$-treated dendritic cells specifically induce proliferation of FOXP3expressing suppressor T cells," Blood, vol. 107, no. 11, pp. 4417-4423, 2006.

[197] S. Rutella, G. Bonanno, A. Procoli et al., "Hepatocyte growth factor favors monocyte differentiation into regulatory interleukin (IL)-10IL-12 accessory cells with dendritic-cell features," Blood, vol. 108, no. 1, pp. 218-227, 2006.

[198] S. Vigouroux, E. Yvon, E. Biagi, and M. K. Brenner, "Antigeninduced regulatory T cells," Blood, vol. 104, no. 1, pp. 26-33, 2004.

[199] N. Watanabe, Y. H. Wang, H. K. Lee et al., "Hassall's corpuscles instruct dendritic cells to induce CD4 CD25 regulatory T cells in human thymus," Nature, vol. 436, no. 7054, pp. 1181-1185, 2005.

[200] E. S. Yvon, S. Vigouroux, R. F. Rousseau et al., "Overexpression of the Notch ligand, Jagged-1, induces alloantigenspecific human regulatory T cells," Blood, vol. 102, no. 10, pp. 3815-3821, 2003.

[201] M. V. Dhodapkar, R. M. Steinman, J. Krasovsky, C. Munz, and N. Bhardwaj, "Antigen-specific inhibition of effector T cell function in humans after injection of immature dendritic cells," Journal of Experimental Medicine, vol. 193, no. 2, pp. 233-238, 2001.

[202] H. Jonuleit, E. Schmitt, G. Schuler, J. Knop, and A. H. Enk, "Induction of interleukin 10-producing, nonproliferating $\mathrm{CD}^{+} \mathrm{T}$ cells with regulatory properties by repetitive stimulation with allogeneic immature human dendritic cells," Journal of Experimental Medicine, vol. 192, no. 9, pp. 12131222, 2000.

[203] S. Yamazaki, T. Iyoda, K. Tarbell et al., "Direct expansion of functional $\mathrm{CD} 25^{+} \mathrm{CD} 4^{+}$regulatory $\mathrm{T}$ cells by antigenprocessing dendritic cells," Journal of Experimental Medicine, vol. 198, no. 2, pp. 235-247, 2003.

[204] C. Brinster and E. M. Shevach, "Bone marrow-derived dendritic cells reverse the anergic state of $\mathrm{CD} 4^{+} \mathrm{CD} 25^{+} \mathrm{T}$ cells without reversing their suppressive function," Journal of Immunology, vol. 175, no. 11, pp. 7332-7340, 2005.

[205] K. V. Tarbell, S. Yamazaki, K. Olson, P. Toy, and R. M. Steinman, "CD25 ${ }^{+} \mathrm{CD} 4^{+} \mathrm{T}$ cells, expanded with dendritic cells presenting a single autoantigenic peptide, suppress autoimmune diabetes," Journal of Experimental Medicine, vol. 199, no. 11, pp. 1467-1477, 2004.

[206] J. Harnaha, J. Machen, M. Wright et al., "Interleukin-7 is a survival factor for $\mathrm{CD}^{+} \mathrm{CD} 25^{+} \mathrm{T}$-cells and is expressed by diabetes-suppressive dendritic cells," Diabetes, vol. 55, no. 1, pp. 158-170, 2006.

[207] P. Chappert, M. Leboeuf, P. Rameau et al., "Antigen-driven interactions with dendritic cells and expansion of Foxp3+ regulatory $\mathrm{T}$ cells occur in the absence of inflammatory signals," Journal of Immunology, vol. 180, no. 1, pp. 327-334, 2008.

[208] R. J. DiPaolo, C. Brinster, T. S. Davidson, J. Andersson, D. Glass, and E. M. Shevach, "Autoantigen-specific TGFbetainduced Foxp3+ regulatory T cells prevent autoimmunity by inhibiting dendritic cells from activating autoreactive T cells,"
The Journal of Immunology, vol. 179, no. 7, pp. 4685-4693, 2007.

[209] T. Lehner, "Special regulatory T cell review: the resurgence of the concept of contrasuppression in immunoregulation," Immunology, vol. 123, no. 1, pp. 40-44, 2008.

[210] Y. Onishi, Z. Fehervari, T. Yamaguchi, and S. Sakaguchi, "Foxp3+ natural regulatory T cells preferentially form aggregates on dendritic cells in vitro and actively inhibit their maturation," Proceedings of the National Academy of Sciences of the United States of America, vol. 105, no. 29, pp. 1011310118, 2008.

[211] G. Xia, J. He, and J. R. Leventhal, "Ex vivo-expanded natural CD4CD25 regulatory T cells synergize with host Tcell depletion to promote long-term survival of allografts," American Journal of Transplantation, vol. 8, no. 2, pp. 298306, 2008.

[212] E. J. Gordon, L. S. Wicker, L. B. Peterson et al., "Autoimmune diabetes and resistance to xenograft transplantation tolerance in NOD mice," Diabetes, vol. 54, no. 1, pp. 107-115, 2005.

[213] T. G. Markees, D. V. Serreze, N. E. Phillips et al., "NOD mice have a generalized defect in their response to transplantation tolerance induction," Diabetes, vol. 48, no. 5, pp. 967-974, 1999.

[214] T. Pearson, T. G. Markees, D. V. Serreze et al., "Genetic disassociation of autoimmunity and resistance to costimulation blockade-induced transplantation tolerance in nonobese diabetic mice," Journal of Immunology, vol. 171, no. 1, pp. 185-195, 2003.

[215] T. Pearson, T. G. Markees, D. V. Serreze et al., "Islet cell autoimmunity and transplantation tolerance: two distinct mechanisms?" Annals of the New York Academy of Sciences, vol. 1005, pp. 148-156, 2003.

[216] T. Pearson, T. G. Markees, L. S. Wicker et al., "NOD congenic mice genetically protected from autoimmune diabetes remain resistant to transplantation tolerance induction," Diabetes, vol. 52, no. 2, pp. 321-326, 2003.

[217] A. A. Rossini, "Autoimmune diabetes and the circle of tolerance," Diabetes, vol. 53, no. 2, pp. 267-275, 2004.

[218] A. A. Rossini, J. P. Mordes, D. L. Greiner, and J. S. Stoff, "Islet cell transplantation tolerance," Transplantation, vol. 72, no. 8, pp. S43-S46, 2001.

[219] E. Seung, J. P. Mordes, D. L. Greiner, and A. A. Rossini, "Induction of tolerance for islet transplantation for type 1 diabetes," Current Diabetes Reports, vol. 3, no. 4, pp. 329-335, 2003.

[220] B. Ludewig, B. Odermatt, S. Landmann, H. Hengartner, and R. M. Zinkernagel, "Dendritic cells induce autoimmune diabetes and maintain disease via de novo formation of local lymphoid tissue," Journal of Experimental Medicine, vol. 188, no. 8, pp. 1493-1501, 1998.

[221] R. J. Creusot, S. S. Yaghoubi, P. Chang et al., "Lymphoid tissue-specific homing of bone marrow-derived dendritic cells," Blood, vol. 113, no. 26, pp. 6638-6647, 2009.

[222] R. J. Creusot, P. Chang, D. G. Healey, I. Y. Tcherepanova, C. A. Nicolette, and C. G. Fathman, "A short pulse of IL-4 delivered by DCs electroporated with modified mRNA can both prevent and treat autoimmune diabetes in NOD mice," Molecular Therapy, vol. 18, pp. 2112-2120, 2010.

[223] E. Godebu, D. Summers-Torres, M. M. Lin, B. J. Baaten, and L. M. Bradley, "Polyclonal adaptive regulatory CD4 cells that can reverse type I diabetes become oligoclonal long-term protective memory cells," Journal of Immunology, vol. 181, no. 3, pp. 1798-1805, 2008. 
[224] Q. Tang, K. J. Henriksen, M. Bi et al., "In vitro-expanded antigen-specific regulatory $\mathrm{T}$ cells suppress autoimmune diabetes," Journal of Experimental Medicine, vol. 199, no. 11, pp. 1455-1465, 2004.

[225] S. E. Weber, J. Harbertson, E. Godebu et al., "Adaptive isletspecific regulatory $\mathrm{CD} 4 \mathrm{~T}$ cells control autoimmune diabetes and mediate the disappearance of pathogenic Th1 cells in vivo," Journal of Immunology, vol. 176, no. 8, pp. 4730-4739, 2006.

[226] R. Gandhi, D. Kumar, E. J. Burns et al., "Activation of the aryl hydrocarbon receptor induces human type 1 regulatory $\mathrm{T}$ cell-like and Foxp3+ regulatory T cells," Nature Immunology, vol. 11, no. 9, pp. 846-853, 2010.

[227] L. Apetoh, F. J. Quintana, C. Pot et al., "The aryl hydrocarbon receptor interacts with c-Maf to promote the differentiation of type 1 regulatory $\mathrm{T}$ cells induced by IL-27," Nature Immunology, vol. 11, no. 9, pp. 854-861, 2010.

[228] V. R. Sinha and A. Trehan, "Biodegradable microspheres for parenteral delivery," Critical Reviews in Therapeutic Drug Carrier Systems, vol. 22, no. 6, pp. 535-602, 2005.

[229] M. E. Keegan and W. M. Saltzman, "Surface-modified biodegradable microspheres for DNA vaccine delivery," Methods in Molecular Medicine, vol. 127, pp. 107-113, 2006.

[230] F. H. Xu and Q. Zhang, "Recent advances in the preparation progress of protein/peptide drug loaded PLA/PLGA microspheres," Yao Xue Xue Bao, vol. 42, no. 1, pp. 1-7, 2007.

[231] S. Tamilvanan, R. V. Babu, K. Kannan, S. K. Basu, and B. Sa, "Manufacturing techniques and excipients used during the design of biodegradable polymer-based microspheres containing therapeutic peptide/protein for parenteral controlled drug delivery," PDA Journal of Pharmaceutical Science and Technology, vol. 62, no. 2, pp. 125-154, 2008.

[232] B. Phillips, K. Nylander, J. Harnaha et al., "A microspherebased vaccine prevents and reverses new-onset autoimmune diabetes," Diabetes, vol. 57, no. 6, pp. 1544-1555, 2008.

[233] S. Tsai, A. Shameli, J. Yamanouchi et al., "Reversal of autoimmunity by boosting memory-like autoregulatory $\mathrm{T}$ cells," Immunity, vol. 32, no. 4, pp. 568-580, 2010.

[234] L. Glass-Marmor, T. Paperna, Y. Galboiz, and A. Miller, "Immunomodulation by chronobiologically-based glucocorticoids treatment for multiple sclerosis relapses," Journal of Neuroimmunology, vol. 210, no. 1-2, pp. 124-127, 2009.

[235] O. Karabay, A. Temel, A. G. Koker, M. Tokel, M. Ceyhan, and E. Kocoglu, "Influence of circadian rhythm on the efficacy of the hepatitis B vaccination," Vaccine, vol. 26, no. 9, pp. 11431144, 2008.

[236] P. Lissoni, "Modulation of anticancer cytokines IL-2 and IL-12 by melatonin and the other pineal indoles 5methoxytryptamine and 5-methoxytryptophol in the treatment of human neoplasms," Annals of the New York Academy of Sciences, vol. 917, pp. 560-567, 2000.

[237] P. H. Langlois, M. H. Smolensky, W. P. Glezen, and W. A. Keitel, "Diurnal variation in responses to influenza vaccine," Chronobiology International, vol. 12, no. 1, pp. 28-36, 1995.

[238] S. Gurkan, Y. Luan, N. Dhillon et al., "Immune reconstitution following rabbit antithymocyte globulin," American Journal of Transplantation, vol. 10, no. 9, pp. 2132-2141, 2010.

[239] A. Palanichamy, J. Barnard, B. Zheng et al., "Novel human transitional B cell populations revealed by B cell depletion therapy," Journal of Immunology, vol. 182, no. 10, pp. 5982 5993, 2009.
[240] B. Regnault, Y. F. J. Osorio, D. Miao, G. Eisenbarth, and E. Melanitou, "Early over expression of messenger RNA for multiple genes, including insulin, in the Pancreatic Lymph Nodes of NOD mice is associated with Islet Autoimmunity," BMC Medical Genomics, vol. 2, article 63, 2009.

[241] L. Yip, L. Su, D. Sheng et al., "Deaf1 isoforms control the expression of genes encoding peripheral tissue antigens in the pancreatic lymph nodes during type 1 diabetes," Nature Immunology, vol. 10, no. 9, pp. 1026-1033, 2009.

[242] S. Pang, L. Zhang, H. Wang et al., "CD8 ${ }^{+} \mathrm{T}$ cells specific for $\beta$ cells encounter their cognate antigens in the islets of NOD mice," European Journal of Immunology, vol. 39, no. 10, pp. 2716-2724, 2009.

[243] B. Calderon, A. Suri, M. J. Miller, and E. R. Unanue, "Dendritic cells in islets of Langerhans constitutively present beta cell-derived peptides bound to their class II MHC molecules," Proceedings of the National Academy of Sciences of the United States of America, vol. 105, no. 16, pp. 6121-6126, 2008.

[244] K. M. Wheeler, E. T. Samy, and K. S. K. Tung, "Cutting edge: normal regional lymph node enrichment of antigen-specific regulatory $\mathrm{T}$ cells with autoimmune disease-suppressive capacity," Journal of Immunology, vol. 183, no. 12, pp. 76357638, 2009.

[245] E. T. Samy, L. A. Parker, C. P. Sharp, and K. S. K. Tung, "Continuous control of autoimmune disease by antigendependent polyclonal $\mathrm{CD} 4{ }^{+} \mathrm{CD} 25^{+}$regulatory $\mathrm{T}$ cells in the regional lymph node," Journal of Experimental Medicine, vol. 202, no. 6, pp. 771-781, 2005.

[246] J. C. Ochando, A. C. Yopp, Y. Yang et al., "Lymph node occupancy is required for the peripheral development of alloantigen-specific Foxp $3^{+}$regulatory T cells," Journal of Immunology, vol. 174, no. 11, pp. 6993-7005, 2005.

[247] T. Hiura, H. Kagamu, S. Miura et al., "Both regulatory T cells and antitumor effector $\mathrm{T}$ cells are primed in the same draining lymph nodes during tumor progression," Journal of Immunology, vol. 175, no. 8, pp. 5058-5066, 2005. 


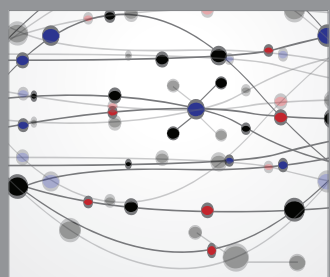

The Scientific World Journal
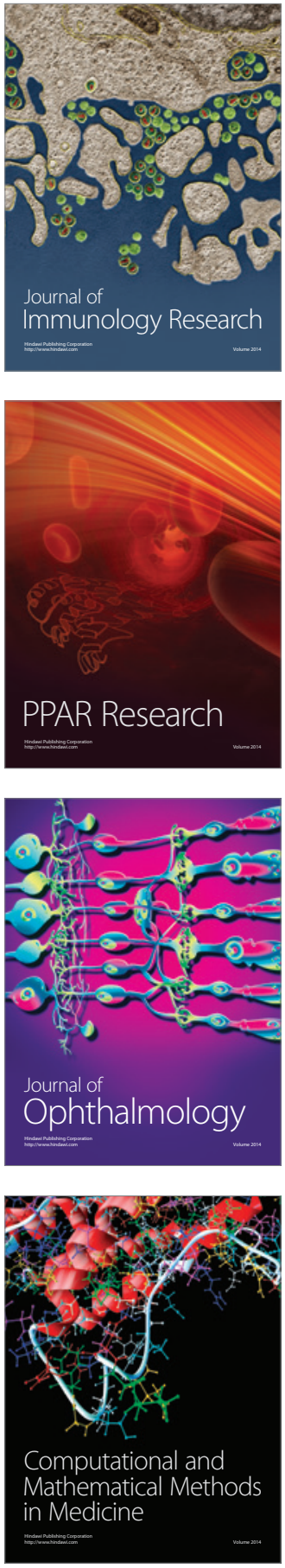

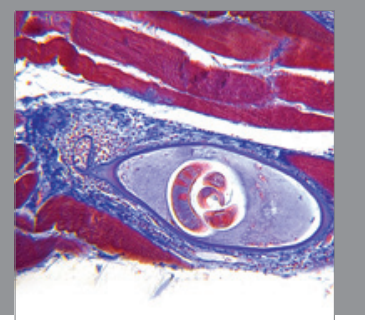

Gastroenterology

Research and Practice
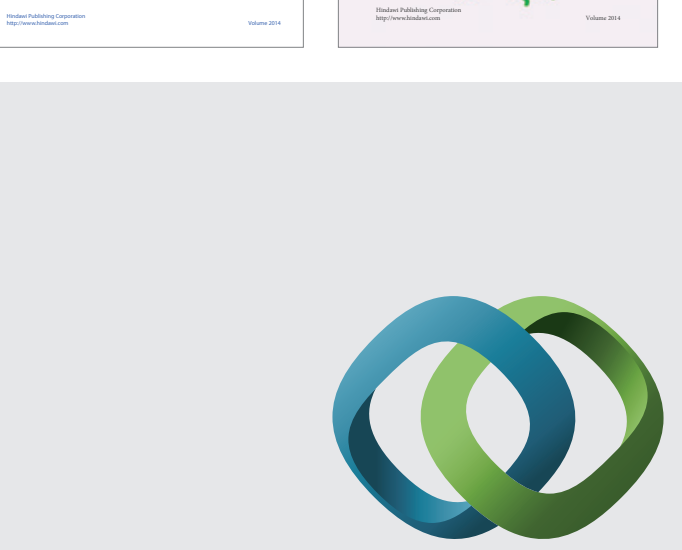

\section{Hindawi}

Submit your manuscripts at

http://www.hindawi.com
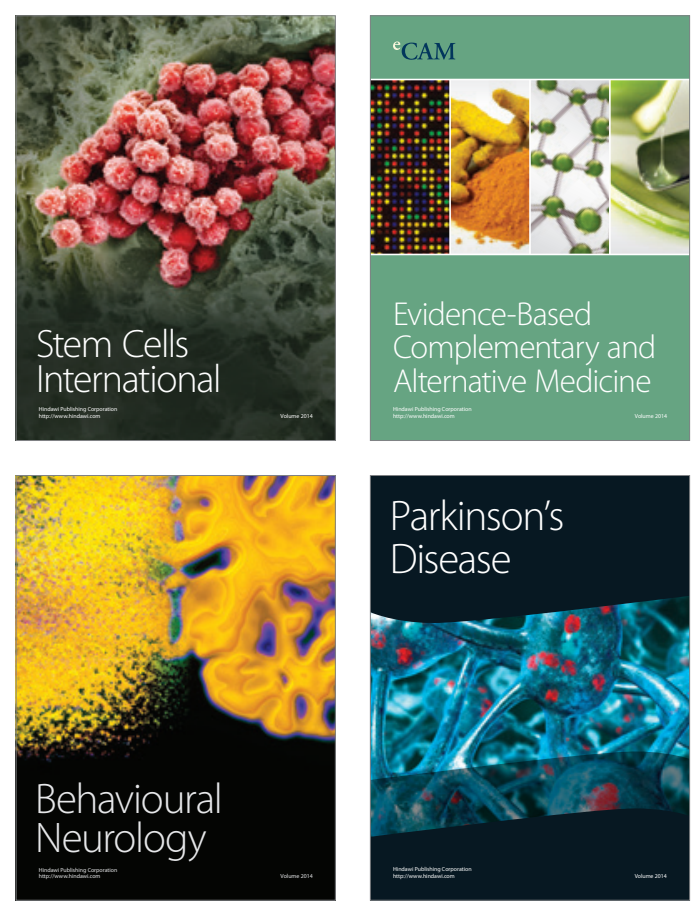

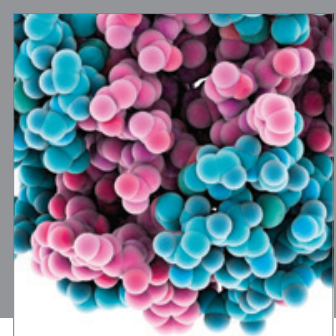

Journal of
Diabetes Research

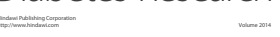

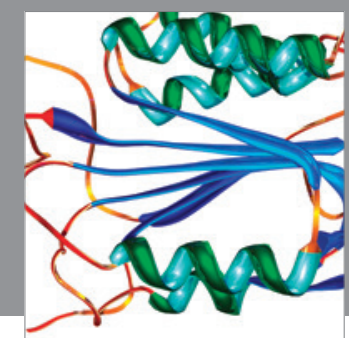

Disease Markers
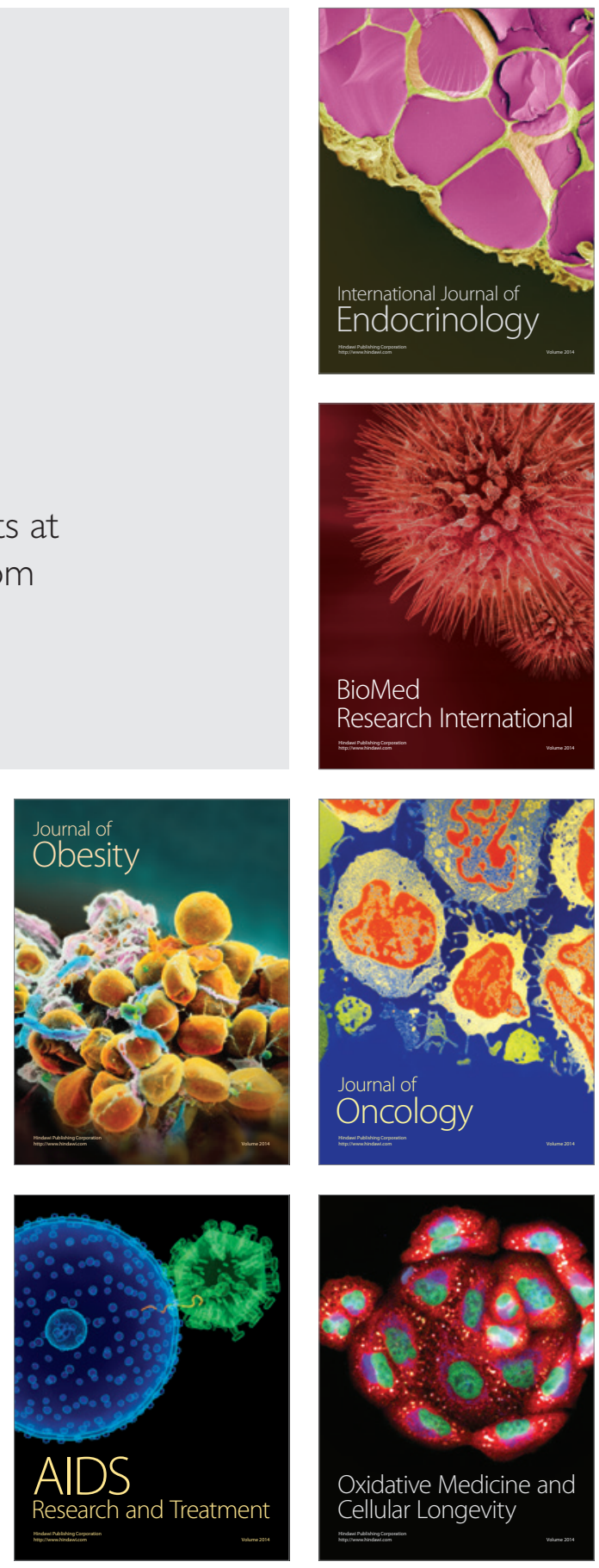